Article

\title{
Calcium-Bearing Minerals Transformation during Underground Coal Gasification
}

\author{
Shuqin Liu * and Weiping Ma
}

School of Chemical and Environmental Engineering, China University of Mining and Technology (Beijing), Beijing 100083, China; 13260239766@163.com

* Correspondence: liushuqin@cumtb.edu.cn; Tel.: +86-10-6233-9156

Received: 20 October 2019; Accepted: 13 November 2019; Published: 15 November 2019

\begin{abstract}
Calcium-bearing minerals are one of the main typical minerals in coal and coal ash. In the process of coal thermal conversion, calcium-bearing minerals undergo different morphological transformation in which the reaction temperature, pressure, and atmosphere are important factors affecting their transformation. The reaction process of underground coal gasification (UCG) could be clearly divided into pyrolysis, reduction, and oxidation and the typical calcium-bearing minerals are expected to indicate the actual reaction conditions of UCG. A high-calcium coal, Zhundong coal, was used in this research. The products of UCG were prepared and the minerals were identified by X-ray diffraction (XRD) and a scanning electron microscope coupled with an energy-dispersive spectrometer (SEM-EDS). The thermodynamic calculation was used to assist in understanding the transformation behaviors of calcium-bearing minerals. The experimental results show that the calcium-bearing mineral is gradually converted from gypsum $\left(\mathrm{CaSO}_{4} \cdot 2 \mathrm{H}_{2} \mathrm{O}\right)$ in the raw coal into anhydrite $\left(\mathrm{CaSO}_{4}\right)$ during the pyrolysis process. In the reduction stage, anhydrite reacts with the reducing gas $(\mathrm{CO})$ to produce oldhamite $(\mathrm{CaS})$, and the oldhamite is stably present in the reduction ash. During the oxidation process, oldhamite is first transformed into $\mathrm{CaSO}_{4}$, and then $\mathrm{CaSO}_{4}$ is converted into $\mathrm{CaO}$. Finally, $\mathrm{CaO}$ reacts with $\mathrm{Al}_{2} \mathrm{O}_{3}$ and $\mathrm{SiO}_{2}$ to produce gehlenite $\left(\mathrm{Ca}_{2} \mathrm{Al}_{2} \mathrm{SiO}_{7}\right)$ at $1100{ }^{\circ} \mathrm{C}$. As the oxidation temperature rises to $1400{ }^{\circ} \mathrm{C}$, gehlenite is transformed into the thermodynamically stable anorthite $\left(\mathrm{CaAl}_{2} \mathrm{Si}_{2} \mathrm{O}_{8}\right)$. With the further progress of the reaction, anorthite will co-melt with iron-bearing minerals above $1500{ }^{\circ} \mathrm{C}$. The ternary phase diagram of $\mathrm{SiO}_{2}-\mathrm{Al}_{2} \mathrm{O}_{3}-\mathrm{CaO}$ system proves that anorthite and gehlenite are the typical high-temperature calcium-bearing minerals when the mole fraction of $\mathrm{SiO}_{2}$ is higher than 0.6. Moreover, the gehlenite is converted to anorthite with the temperature rise, which is consistent with experimental results. This study provides a scientific basis for understanding the UCG reaction conditions.
\end{abstract}

Keywords: underground coal gasification; high-calcium coal; calcium-bearing minerals; coal ash

\section{Introduction}

Coal is a complex geologic material composed mainly of organic matter and mineral matter. Minerals play a significant role in affecting the coal utilization process, especially coal combustion and gasification processes. Minerals also are the major hosts of most elements present in coal [1]. After thermal transformation of coal (pyrolysis, combustion, gasification), minerals and other inorganic components in coal break down, agglomerate, and melt, mainly forming ash and slag [2]. Calcium-bearing minerals are common minerals in coal and have an important influence on coal combustion and gasification processes. According to the chemical composition and properties of coal, coal with $\mathrm{CaO}$ content more than $15 \%$ is identified as high-calcium coal [3]. Zhundong coal is a typical high-calcium coal. Zhundong coal, located in the east of Junggar Basin, Xinjiang, China, with the forecast coal reserves of 390 billion tons, is the largest intact coalfield in the world. Zhundong 
coal accounts for $17.8 \%$ of Xinjiang's coal reserves and 7.2\% of China's coal reserves [4]. Due to characteristics of high volatile substances, Zhundong coal is easily ignited. However, the severe scaling and slagging problems during the pyrolysis or combustion process limit its utilization as cleaning fuel [5]. The main reason is due to the high contents of alkali and alkaline earth metallic species (AAEMs) in the coal [6,7]. Underground coal gasification can solve the ash-related problems (fouling, slagging, agglomeration) of Zhundong coal because it does not need a boiler or gasifier facility. This paper focuses on the transformation of calcium-bearing minerals during the UCG process.

It is reported that calcium-bearing minerals have an important influence on the coal utilization process [8,9]. $\mathrm{CaO}$ promotes pyrolysis, and adsorbs pyrolysis products in the early stage, and then $\mathrm{CaO}$ has a catalytic effect on deoxygenation and dealkylation, which increases coal weight loss. Calcium is an important in-situ catalyst and plays a catalytic role in coal gasification. Alkali metals (Na, K) and alkaline earth metal $(\mathrm{Ca})$ compounds can also reduce the ignition temperature of coal and have the effect of denitrification and desulfurization. Furthermore, the phenomenon of sublimation of calcium-bearing minerals in coal occurs at high temperature, which is the initial cause of slagging on the heated surface [10].

Underground coal gasification (UCG) is the process in which the coal is directly converted into combustible gaseous products $\left(\mathrm{CO}, \mathrm{H}_{2}, \mathrm{CH}_{4}\right)$ [11]. Underground coal gasification can effectively solve the safety and environmental problems caused by coal mining, improve the efficiency of coal utilization, and solve the problem of "rich coal" and "lack gas" in China. In view of the problems existing in the utilization of Zhundong coal, it is hoped that the underground coal gasification technology will be used for the exploitation of Zhundong coal.

The basic principle of underground coal gasification is the same as that of surface gasification, but the reaction process is different. The characteristics of underground coal gasification are the fixation of gasified coal and the movement of gasification working face [12]. The actual reaction conditions of UCG are difficult to monitor because the reaction is usually carried out in coal seams at hundred meters beneath the surface [13]. The mineral characteristics of underground coal gasification ash are closely related to the actual reaction conditions of UCG. Therefore, the study of mineral characteristics of ash has become an important way to explore the actual reaction conditions of UCG.

Ash deposition and sodium transformation behavior during Zhundong coal combustion have been studied by many authors [14]. Kosminski et al. [15,16] have found that temperature exerted important effects on reactions between $\mathrm{Na}$ compounds and $\mathrm{SiO}_{2}$ and $\mathrm{Al}_{2} \mathrm{O}_{3}$, thus affecting $\mathrm{Na}$ release. Li et al. [17] have reported that $\mathrm{NaCl}$ is the main form released from Zhundong coal and that $80 \%$ of $\mathrm{Na}$ is released from the coal as temperature increases from $600-800{ }^{\circ} \mathrm{C}$ during combustion. Zhang et al. [18] have investigated the effects of temperature on $\mathrm{Na}$ transformation of Zhundong coal in a fluidized bed gasifier. The Na retention ratio was found to initially decrease but then increase with increased temperature, and more sodium was retained in residuals at high temperatures [19]. However, studies on the conversion of calcium-bearing minerals are insufficient during Zhundong coal gasification, especially the UCG process. At present, several methods have been applied to solve the fouling and slagging problems, such as coal blending, additive application, and coal leaching. Coal blending can alleviate the fouling and slagging problems, but the blending ratio of Zhundong coal is low and is limited by the high transport expense of coal with low AAEM content [4]. Li et al. proposed a new method of $\mathrm{CO}_{2}$-water leaching to remove AAEM in Zhundong coal, the removal efficiencies of $\mathrm{Na}$ and Ca were up to $90.5 \%$ and $31.1 \%$, respectively [20].

Based on the deficiencies in the previous studies, the aim of this work is to investigate the sequential transformation of calcium-bearing minerals during UCG process. Laboratory UCG simulation experiments were used to prepare UCG semi-coke $\left(800^{\circ} \mathrm{C}\right)$, reduction ash $\left(900^{\circ} \mathrm{C}-1300^{\circ} \mathrm{C}\right)$, and oxidation ash $\left(1100{ }^{\circ} \mathrm{C}-1500^{\circ} \mathrm{C}\right)$ based on the Zhundong coal. The XRD, SEM-EDS, and FactSage 7.3 were performed to identify the composition and microstructure of the calcium-bearing minerals obtained from the ashes at different atmospheres and temperatures. 


\section{Experimental Section}

\subsection{Sample Preparation}

Zhundong coal was used in this study. The Zhundong coal is taken from Zhundong coalfield, Changji Hui Autonomous Prefecture, Xinjiang, China. Zhundong coalfield, Junggar basin, comprises the Upper Permian Xiachangfanggou group $\left(\mathrm{P}_{2} \mathrm{ch}^{\mathrm{a}}\right)$, the Middle-Upper Triassic Xiaoquangou group $\left(\mathrm{T}_{2-3} \times \mathrm{q}\right)$, the Lower Jurassic Badaowan $\left(\mathrm{J}_{1} \mathrm{~b}\right)$ and Sangonghe formations $\left(\mathrm{J}_{1} \mathrm{~s}\right)$, the Middle Jurassic Xishanyao formation $\left(\mathrm{J}_{2} \mathrm{x}\right)$, the Middle-Upper Jurassic Shishugou group $\left(\mathrm{J}_{2-3} \mathrm{sh}\right)$, and the Pliocene Dushanzi formation $\left(\mathrm{N}_{2} \mathrm{~d}\right)$. The main coal-bearing strata are interbedded in the Lower Jurassic Badaowan $\left(J_{1} b\right)$ and the Middle Jurassic Xishanyao formations $\left(J_{2} x\right)$. The latter formation contains the main workable coal seams of the basin, whereas the Badaowan formation consists locally of workable coal seams in the Zhundong coalfield [21]. To prevent weathering of the coal sample, original coal was wrapped carefully with polyethylene film, stored in poly (vinyl chloride) (PVC)-sealed containers, and then transported to the laboratory. The coal was carefully ground and sieved to obtain a sample with particle sizes between 3-6 $\mathrm{mm}$ prior to the experiment.

Proximate analysis and ultimate analysis were carried out based on ASTM Standards D3173-11 (2011) [22], D3175-11 (2011) [23], and D3174-11 (2011) [24]. The total sulfur content was analyzed following ASTM Standard D3177-02 (2002) [25]. A scanning wave-length dispersive X-ray fluorescence spectrometer (XRF; Thermo ARL Advant' $\mathrm{XP}+$, Xenemetrix, TX, USA) was used to determine the major-element oxides $\left(\mathrm{SiO}_{2}, \mathrm{TiO}_{2}, \mathrm{Al}_{2} \mathrm{O}_{3}, \mathrm{Fe}_{2} \mathrm{O}_{3}, \mathrm{MgO}, \mathrm{CaO}, \mathrm{MnO}_{2}, \mathrm{Na}_{2} \mathrm{O}, \mathrm{K} 2 \mathrm{O}\right.$, and $\left.\mathrm{P}_{2} \mathrm{O}_{5}\right)$ in high-temperature ashes $\left(815^{\circ} \mathrm{C}\right)$ of the samples, which were prepared as pressed powder mounts. The loss on ignition (LOI) for sample was also determined at this temperature.

\subsection{Experimental Installation and Process}

As shown in Figure 1A, the multifunctional pyrolysis/gasification experimental system (HWD-500, Beijing Henven Scientific Instrument Factory, Beijing, China) was used to determine the reaction time of pyrolysis, reduction, and the oxidation stages during the UCG process. The pyrolysis, reduction, and oxidation experiments were conducted in a high-temperature pipe furnace (shown in Figure 1B). During the pyrolysis process, coal samples were placed in the experimental system with $\mathrm{N}_{2}(2 \mathrm{~L} / \mathrm{min})$ protective atmosphere. The temperature rises from room temperature to $800{ }^{\circ} \mathrm{C}$, the heating rate is $5{ }^{\circ} \mathrm{C} / \mathrm{min}$, and the constant temperature is $30 \mathrm{~min}$; during the reduction stage, $\mathrm{H}_{2} \mathrm{O}(\mathrm{g})(5 \mathrm{~g} / \mathrm{min})$ and $\mathrm{CO}_{2}(2 \mathrm{~L} / \mathrm{min})$ were injected into the experimental system, the completion times of the reduction process from $900{ }^{\circ} \mathrm{C}$ to $1300{ }^{\circ} \mathrm{C}$ were $55 \mathrm{~min}, 40 \mathrm{~min}, 25 \mathrm{~min}, 15 \mathrm{~min}$, and $20 \mathrm{~min}$, respectively; during the oxidation stage, the completion time of the oxidation process from $1100^{\circ} \mathrm{C}$ to $1500^{\circ} \mathrm{C}$ was about $60 \mathrm{~min}$. After the pyrolysis char/reduction ash/oxidation ash cools to room temperature, the char/slag is taken out from the furnace and sealed for analysis. 

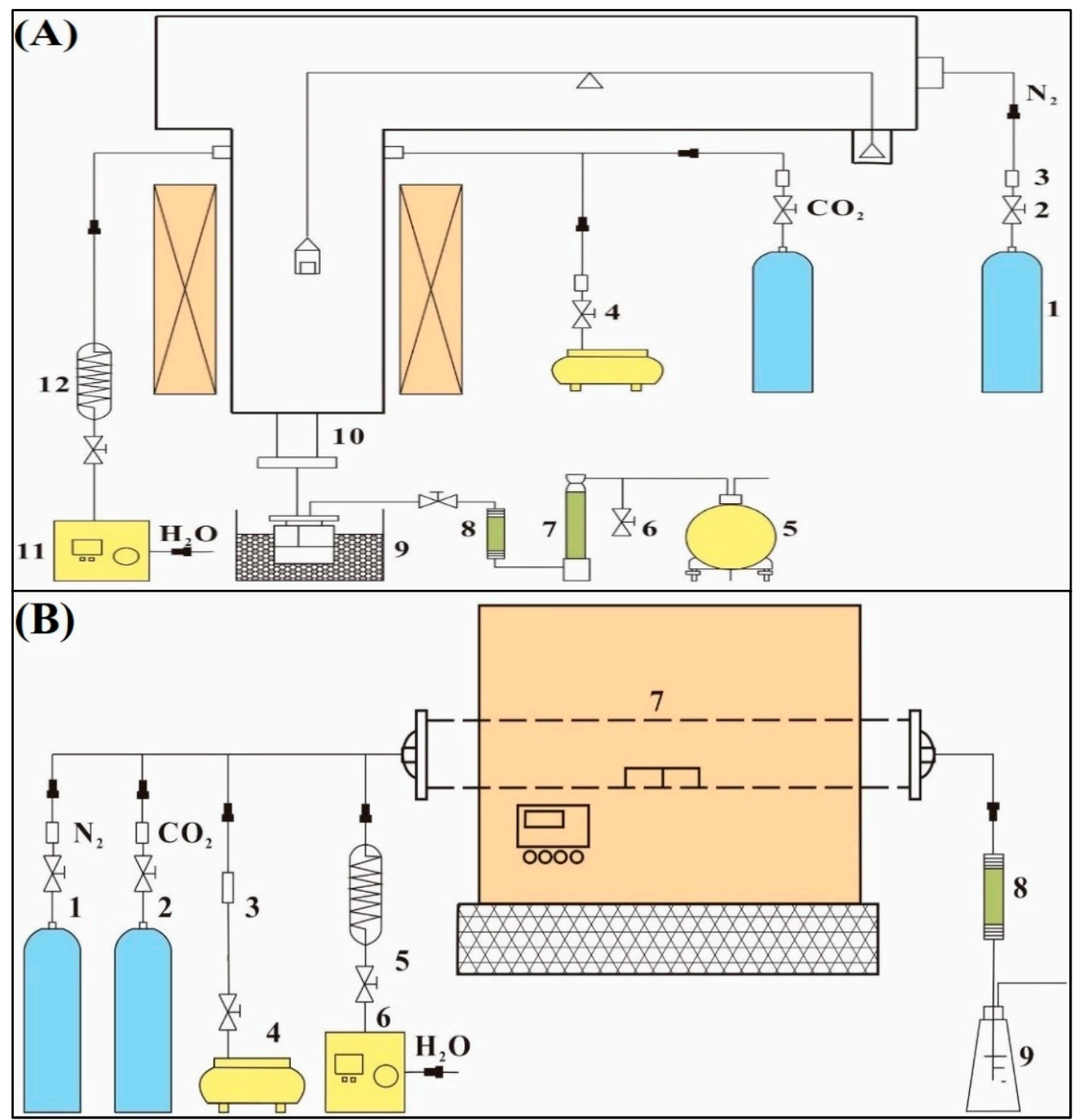

Figure 1. Schematic diagram of the experimental system used in this study. (A) Multifunctional pyrolysis/gasification experimental system. 1, cylinders; 2, needle valve; 3, pressure gauge; 4, air compressor; 5, wet-type gas flowmeter; 6, sampling port; 7, dryer; 8, secondary tar absorption device; 9, cold water bath; 10, thermobalance; 11, plunger pump; 12, steam generator. (B) high-temperature tube furnace. 1, cylinders; 2, needle valve; 3 , pressure gauge; 4 , air compressor; 5, water steam generator; 6 , plunger pump; 7, high temperature tube furnace; 8 , tar absorber; 9 , gas bottle [13].

\subsection{Sample Characterization}

The mineralogical characterization of the coal and the products of different reaction stages was identified by X-ray powder diffraction (XRD) (D/max-2500/pc XRD, Rigaku, Japan) with a scanning rate of $8^{\circ} / \mathrm{min}$ from $5^{\circ}$ to $90^{\circ}$. A field emission scanning electron microscope (FE-SEM, MERLIN Compact, Zeiss, Jena, Germany) and an energy dispersive X-ray spectrometer (EDS, INCA, Oxford, UK) were used to study the morphology and compositions of raw coal, ash, and slag, as well as the distribution of main elements [26].

\subsection{Thermodynamic Equilibrium Calculation}

FactSage can be used as a powerful predictive tool to predict the multiphase equilibria, as well as the transformation behaviors of minerals at different temperatures. Thus, the "Phase diagram" and "Equilib" in FactSage $7.3\left(\mathrm{~F}^{*} \mathrm{~A}^{*} \mathrm{C}^{*} \mathrm{~T} / \mathrm{FACT}\right.$-Win and ChemSage) was used to calculate the mineral transformation and slag formation process in a specified atmosphere. For the calculations, the equilibrium module 
was employed together with the databases Ftoxid and FactPs [27]. Additionally, the solution phases of Ftoxid-SLAG and Ftoxid-oPyr were selected to simulate the gasification. During the reduction stage, calculation was performed at temperature ranging from $900-1300{ }^{\circ} \mathrm{C}$ with the constant pressure of $0.1 \mathrm{MPa}$. During the oxidation process, the temperature varies from $1100-1500{ }^{\circ} \mathrm{C}$ with the constant pressure of 0.1 MPa. Since the amount of ash in coal is the sum of the mineral composition of coal such as $\mathrm{Al}_{2} \mathrm{O}_{3}, \mathrm{SiO}_{2}, \mathrm{Fe}_{2} \mathrm{O}_{3}, \mathrm{MgO}, \mathrm{TiO}_{2}, \mathrm{MnO}_{2}, \mathrm{SO}_{3}, \mathrm{P}_{2} \mathrm{O}_{5}, \mathrm{~K}_{2} \mathrm{O}, \mathrm{Na}_{2} \mathrm{O}$, and $\mathrm{CaO}$, the input into the FactSage as shown in Table 1 is done in elemental form. The reduction agent $\mathrm{CO}_{2}$ and $\mathrm{H}_{2} \mathrm{O}(\mathrm{g})$, and oxidation agent $\mathrm{O}_{2}$ are also input into calculations [28].

Table 1. Input into calculations.

\begin{tabular}{ccc}
\hline Input Compositions & Reduction Stage $(\mathbf{g})$ & Oxidation Stage $(\mathbf{g})$ \\
\hline $\mathrm{C}$ & 32.76 & 32.76 \\
$\mathrm{H}$ & 1.56 & 1.56 \\
$\mathrm{O}$ & 7.40 & 7.40 \\
$\mathrm{~N}$ & 0.29 & 0.29 \\
$\mathrm{~S}$ & 0.63 & 0.63 \\
$\mathrm{Si}$ & 0.12 & 0.12 \\
$\mathrm{Al}$ & 0.078 & 0.078 \\
$\mathrm{Fe}$ & 0.66 & 0.66 \\
$\mathrm{Ti}$ & 0.0034 & 0.0034 \\
$\mathrm{Ca}$ & 0.34 & 0.34 \\
$\mathrm{Mg}$ & 0.104 & 0.104 \\
$\mathrm{~K}$ & 0.0047 & 0.0047 \\
$\mathrm{Na}$ & 0.049 & 0.049 \\
$\mathrm{Mn}$ & 0.0012 & 0.0012 \\
$\mathrm{P}$ & 0.00024 & 0.00024 \\
$\mathrm{CO}$ & 151.25 & \\
$\mathrm{H}_{2} \mathrm{O}(\mathrm{g})$ & 192.50 & 25.20 \\
$\mathrm{O}_{2}$ & &
\end{tabular}

\section{Results and Discussion}

\subsection{Coal Analysis}

The ultimate, proximate, and ash compositions analyses of the Zhundong coal are illustrated in Table 2. The Zhundong coal (ZD-coal) is characterized by low ash yield $(5.63 \%)$ and the content of fixed carbon is relatively high, reaching $59.62 \%$. The content of $\mathrm{SiO}_{2}$ and $\mathrm{Al}_{2} \mathrm{O}_{3}$ in the test coal is very low, only $8.82 \%$ and $5.25 \%$, respectively, while the content of $\mathrm{CaO}$ is up to $16.72 \%$. Furthermore, coal also contains high levels of $\mathrm{MgO}$ and $\mathrm{Na}_{2} \mathrm{O}$, reaching $6.16 \%$ and $2.34 \%$, respectively. It can be inferred from the ash component analysis that the coal is a typical high-calcium coal. The acidic oxides $\left(\mathrm{SiO}_{2}\right.$ $+\mathrm{Al}_{2} \mathrm{O}_{3}+\mathrm{TiO}_{2}=14.27 \%$ ) mainly increase the melting temperature of coal ash. The content of basic oxides $\left(\mathrm{Fe}_{2} \mathrm{O}_{3}, \mathrm{Na}_{2} \mathrm{O}, \mathrm{K}_{2} \mathrm{O}, \mathrm{CaO}, \mathrm{MgO}\right)$ is 59.11\% [29]. In general, $\mathrm{CaO}, \mathrm{MgO}$, and $\mathrm{Na}_{2} \mathrm{O}$ easily react with $\mathrm{SiO}_{2}$ to form silicates with lower melting points; therefore, basic oxides generally have the effect of lowering the ash melting temperature. Only a small amount of silicate is formed due to the low content of $\mathrm{SiO}_{2}$ in Zhundong coal [30-33]. The melting point of the basic oxide $\mathrm{CaO}\left(2590{ }^{\circ} \mathrm{C}\right)$ and $\mathrm{MgO}\left(2852{ }^{\circ} \mathrm{C}\right)$ is high, which results in a high ash-melting point of the Zhundong coal. Table 1 also shows that the softening temperature of Zhundong coal is $1260{ }^{\circ} \mathrm{C}$. 
Table 2. Proximate/ultimate analysis of Zhundong coal and the chemical compositions of ash and the coal ash fusibility.

\begin{tabular}{|c|c|c|c|c|c|c|c|c|c|c|c|c|}
\hline \multirow{2}{*}{ Sample } & \multicolumn{4}{|c|}{ Proximate Analysis/\% } & \multicolumn{8}{|c|}{ Ultimate Analysis/\% } \\
\hline & $\mathbf{M}_{\mathrm{ad}}$ & $\mathbf{A}_{\mathrm{ad}}$ & $\mathrm{V}_{\mathrm{ad}}$ & $\mathrm{FC}_{\mathrm{ad}}$ & $\mathrm{C}_{\mathrm{ad}}$ & $\mathrm{H}_{\mathrm{ad}}$ & & & & & & \\
\hline \multirow{9}{*}{ ZD-coal } & 11.15 & 5.63 & 30.25 & 59.62 & 63.53 & 3.13 & & & & & & \\
\hline & \multicolumn{12}{|c|}{ Elemental compositions of coal ash, and loss on ignition (LOI, \%) } \\
\hline & $\mathrm{SiO}_{2}$ & $\mathrm{Al}_{2} \mathrm{O}_{3}$ & $\mathrm{Fe}_{2} \mathrm{O}_{3}$ & $\mathrm{CaO}$ & $\mathrm{TiO}_{2}$ & $\mathrm{MgO}$ & $\mathrm{K}_{2} \mathrm{O}$ & $\mathrm{Na}_{2} \mathrm{O}$ & $\mathrm{MnO}_{2}$ & $\mathrm{SO}_{3}$ & $\mathrm{P}_{2} \mathrm{O}_{5}$ & LOI \\
\hline & 8.82 & 5.25 & 33.69 & 16.72 & 0.20 & 6.16 & 0.20 & 2.34 & 0.07 & 24.26 & 0.02 & 1.87 \\
\hline & \multicolumn{12}{|c|}{ Coal ash fusibility $\left({ }^{\circ} \mathrm{C}\right)$ in a weakly-reducing atmosphere } \\
\hline & \multirow{4}{*}{\multicolumn{4}{|c|}{$\begin{array}{c}\text { Deformation temperature (DT) } \\
\text { Softening temperature (ST) } \\
\text { Hemispherical temperature (HT) } \\
\text { Fluid temperature (FT) }\end{array}$}} & \multicolumn{8}{|c|}{1260} \\
\hline & & & & & \multicolumn{8}{|c|}{1260} \\
\hline & & & & & \multicolumn{8}{|c|}{1270} \\
\hline & & & & & \multicolumn{8}{|c|}{1280} \\
\hline
\end{tabular}

Note: M, moisture; A, ash; V, volatile matter; FC, fixed carbon; C, carbon; H, hydrogen; O, oxygen; N, nitrogen; St, total sulfur; ad, air dry basis.

\subsection{Mineral Transformation Behavior during Coal Pyrolysis}

As illustrated by the XRD analysis in Figure 2, the main minerals in Zhundong coal is quartz $\left(\mathrm{SiO}_{2}\right)$, gypsum $\left(\mathrm{CaSO}_{4} \cdot 2 \mathrm{H}_{2} \mathrm{O}\right)$, pyrite $\left(\mathrm{FeS}_{2}\right)$, and siderite $\left(\mathrm{FeCO}_{3}\right)$. Quartz is one of the most common minerals in coal [1], but due to its low content in the raw coal, the XRD diffraction peak is very weak $[34,35]$. Pyrite is the major iron-bearing mineral in raw coal [36]. The major minerals in $800{ }^{\circ} \mathrm{C}$ pyrolysis of semi-coke include pyrrhotite $\left(\mathrm{Fe}_{1-\mathrm{x}} \mathrm{S}\right)$, quartz, anhydrite $\left(\mathrm{CaSO}_{4}\right)$, ankerite $((\mathrm{Ca}, \mathrm{Mg})$ $\left.\mathrm{CO}_{3}\right)$, and illite $\left(\mathrm{K}_{1.5} \mathrm{Al}_{4}\left(\mathrm{Si}_{6.5} \mathrm{Al}_{1.5}\right) \mathrm{O}_{20}(\mathrm{OH})_{4}\right)$ [37,38]. Illite often co-exists with quartz under natural conditions, and it is also the main component of clay minerals [39]. The pyrite in raw coal is gradually transformed into pyrrhotite and gypsum gradually dehydrates to form anhydrite during the pyrolysis process. The reactions are as follows.

$$
\begin{gathered}
\mathrm{FeS}_{2} \rightarrow 1.14 \mathrm{Fe}_{0.877} \mathrm{~S}(\mathrm{~S})+0.43 \mathrm{~S}_{2}(\mathrm{~g}) \\
\mathrm{CaSO}_{4} \cdot 2 \mathrm{H}_{2} \mathrm{O} \rightarrow \mathrm{CaSO}_{4}+2 \mathrm{H}_{2} \mathrm{O}
\end{gathered}
$$

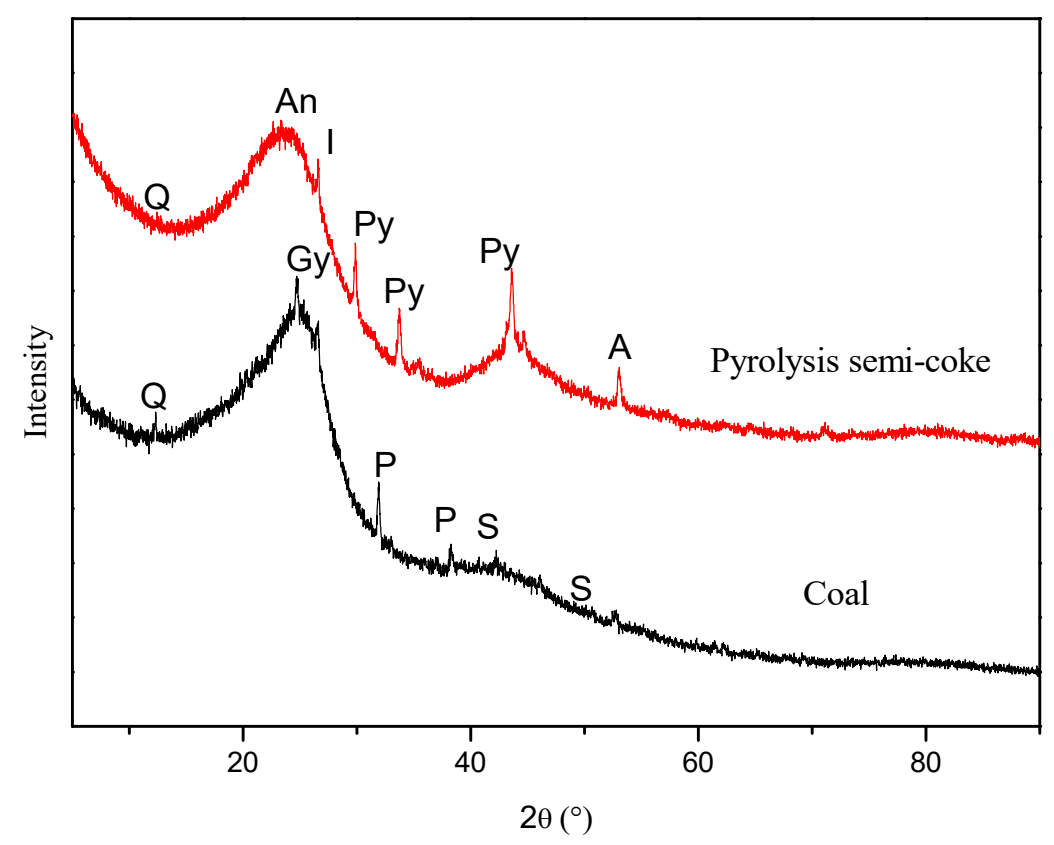

Figure 2. XRD patterns of Zhundong coal and its semi-coke $\left(800{ }^{\circ} \mathrm{C}\right)$. I-illite; Py-pyrrhotite; S—siderite; Q-quartz; P—pyrite; Gy—gypsum; A-Ankerite; An—anhydrite. 
As exhibited in the SEM image in Figure 3B, Fe and $S$ are detected in the semi-coke, which exists in the form of pyrrhotite $\left(\mathrm{Fe}_{1-x} \mathrm{~S}\right)(x=0$ to 0.233$)$. When the pyrolysis temperature exceeds $500{ }^{\circ} \mathrm{C}$, pyrite $\left(\mathrm{FeS}_{2}\right)$ is gradually decomposed, and then $\mathrm{S}$ escapes at a high rate with the temperature further increasing to $800{ }^{\circ} \mathrm{C}$, eventually forming pyrrhotite $\left(\mathrm{Fe}_{0.73} \mathrm{~S}\right)$. Anhydrite also appears in the semi-coke (Figure 3A).

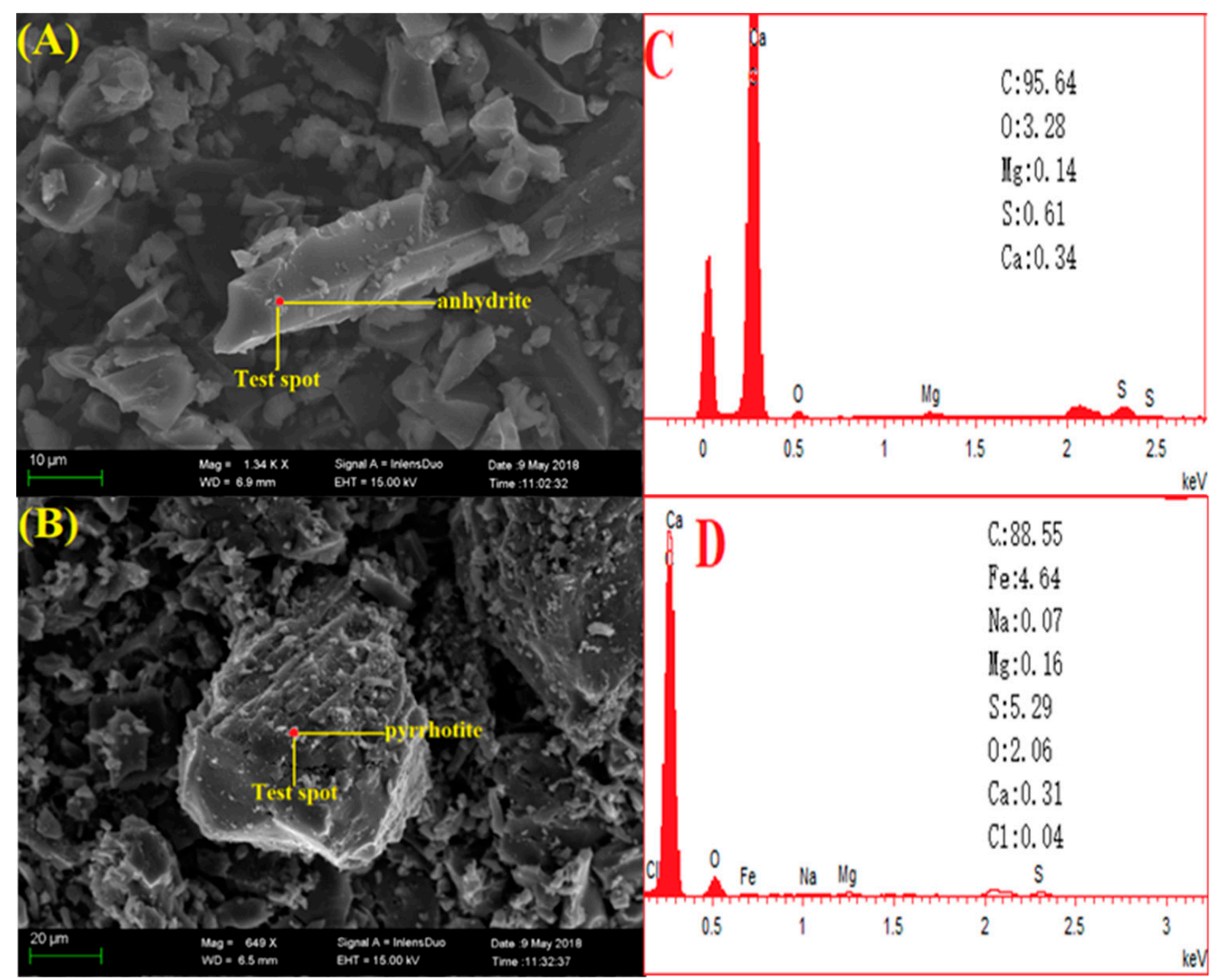

Figure 3. SEM-EDS micrographs of minerals in semi-coke of Zhundong coal (secondary electron images). (A) anhydrite; (B) pyrrhotite; (C) EDS of anhydrite; (D) EDS of pyrrhotite.

\subsection{Mineral Transformation Behavior during the Semi-Coke Reduction Stage}

As exhibited in Figure 4, oldhamite $(\mathrm{CaS})$ and calcite $\left(\mathrm{CaCO}_{3}\right)$ are present in the $900{ }^{\circ} \mathrm{C}$ reduction ash, oldhamite is formed from anhydrite in the semi-coke, and the calcite is formed by the decomposition of ankerite. When the temperature is above $900^{\circ} \mathrm{C}$, anhydrite reacts with the reducing gas (CO) to generate $\mathrm{CaS}$; the reaction is also affected by the $\mathrm{CO}_{2}$ concentration. The reactions are as follows.

$$
\begin{gathered}
\mathrm{CaSO}_{4}+4 \mathrm{CO} \rightarrow \mathrm{CaS}+4 \mathrm{CO}_{2} \\
\mathrm{CaSO}_{4} \rightarrow \mathrm{CaO}+\mathrm{SO}_{3} \\
\mathrm{CaO}+\mathrm{CO}_{2} \rightarrow \mathrm{CaCO}_{3}
\end{gathered}
$$




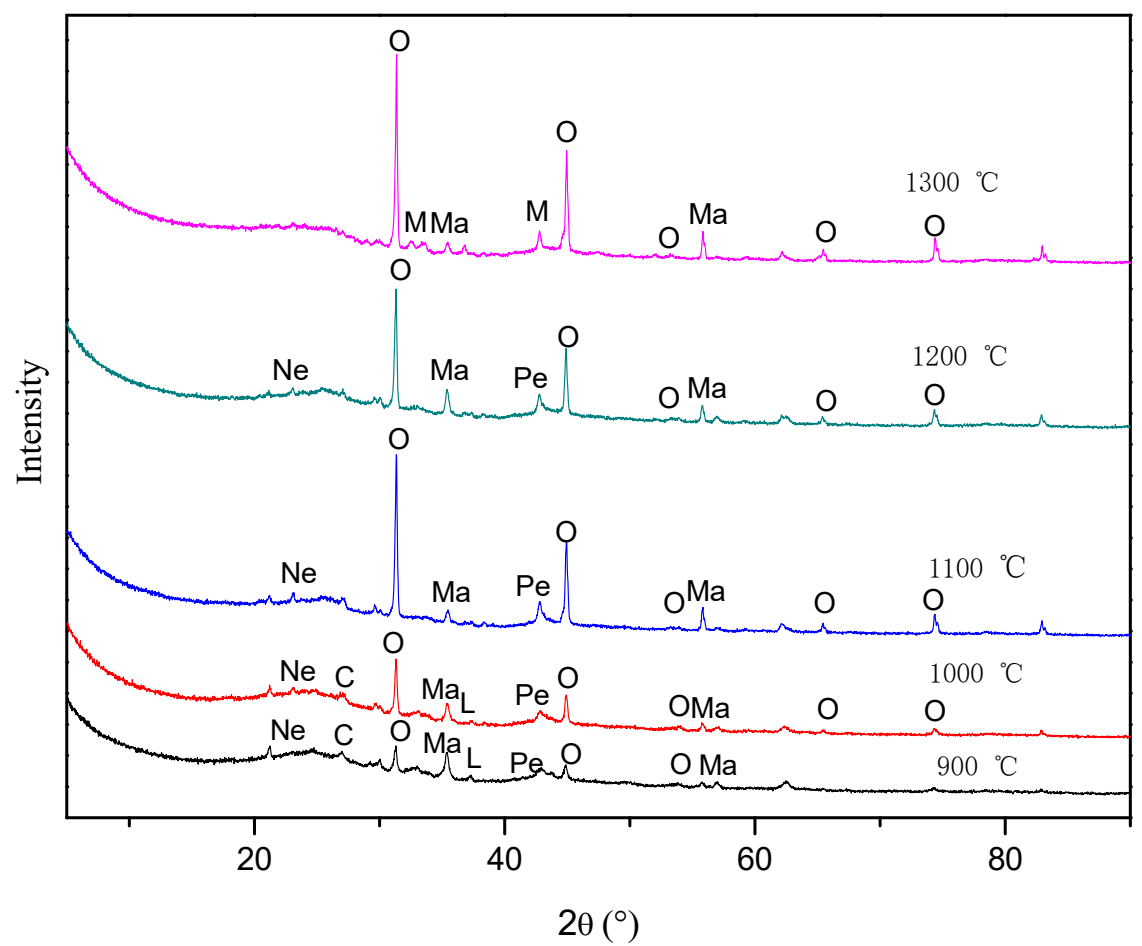

Figure 4. XRD patterns of the ashes obtained from different reduction temperatures. $\mathrm{Ne}-$ nepheline; $\mathrm{Pe}$ - periclase; $\mathrm{O}$-oldhamite; $\mathrm{Ma}$-magnetite; L-lime; C—calcite; $\mathrm{M}$-magnesite.

The characteristic minerals such as periclase $(\mathrm{MgO})$ and nepheline $\left(\mathrm{NaAlSiO}_{4}\right)$ are also detected in the reduction ash. Periclase is detected at $900{ }^{\circ} \mathrm{C}$, which is decomposed from ankerite. Nepheline also formed in the $900^{\circ} \mathrm{C}$ reduction ash. The content of nepheline decreases gradually with the temperature increase [40]. The iron-bearing mineral occurs in the form of magnetite $\left(\mathrm{Fe}_{3} \mathrm{O}_{4}\right)$ in the $900{ }^{\circ} \mathrm{C}$ reduction ash, and it is transformed from pyrrhotite.

As shown in Table 3, it can be inferred that the content of magnetite $\left(\mathrm{Fe}_{3} \mathrm{O}_{4}\right)$ gradually decreases as the reduction temperature increases; trending from $14 \%$ magnetite in the $900{ }^{\circ} \mathrm{C}$ reduction ash to $2 \%$ magnetite at $1300{ }^{\circ} \mathrm{C}$. As the reduction temperature rises, the relative content of oldhamite (CaS) gradually increases from $29 \%$ to $87 \%$. The calcite gradually decreases in the temperature ranging from 900 to $1000{ }^{\circ} \mathrm{C}$ due to the calcite undergoing decomposition with the increase of temperature, and with rapid decomposition in the $812-928^{\circ} \mathrm{C}$ range. Nepheline $\left(\mathrm{NaAlSiO}_{4}\right)$ is also detected in the reduction ash at $900-1200{ }^{\circ} \mathrm{C}$; its content gradually decreases with the increase of temperature. The diffraction peak of nepheline disappears when the temperature reaches $1300^{\circ} \mathrm{C}$, the formation of nepheline is as follows.

$$
\mathrm{Na}_{2} \mathrm{O}+\mathrm{Al}_{2} \mathrm{O}_{3}+2 \mathrm{SiO}_{2} \rightarrow 2 \mathrm{NaAlSiO}_{4}
$$

Table 3. Mineral composition of reduction ash by XRD analysis and Siroquant.

\begin{tabular}{cccccc}
\hline Mineral Composition & $\mathbf{9 0 0}{ }^{\circ} \mathbf{C}$ & $\mathbf{1 0 0 0}{ }^{\circ} \mathbf{C}$ & $\mathbf{1 1 0 0}{ }^{\circ} \mathbf{C}$ & $\mathbf{1 2 0 0}{ }^{\circ} \mathbf{C}$ & $\mathbf{1 3 0 0}{ }^{\circ} \mathbf{C}$ \\
\hline Magnetite & $14 \%$ & $8 \%$ & $7 \%$ & $4 \%$ & $2 \%$ \\
Oldhamite & $29 \%$ & $54 \%$ & $75 \%$ & $80 \%$ & $87 \%$ \\
Lime & $8 \%$ & $2 \%$ & - & - & - \\
Periclase & $10 \%$ & $9 \%$ & $8 \%$ & $7 \%$ & - \\
Calcite & $26 \%$ & $15 \%$ & - & - & - \\
Nepheline & $13 \%$ & $12 \%$ & $10 \%$ & $9 \%$ & - \\
Magnesite & - & - & - & - & $5 \%$ \\
Amorphous & - & - & - & - & $6 \%$ \\
\hline
\end{tabular}


The microstructure of ashes obtained at different reduction temperatures are exhibited in Figure $5 \mathrm{~A}, \mathrm{~B}$, respectively. Nepheline is present at $900{ }^{\circ} \mathrm{C}$ reduction ash, which agrees with the XRD analysis. After the analysis of the ash surface elements, the results (Figure $5 \mathrm{~B}$ ) indicate that the contained elements in the mineral are complex, including $\mathrm{C}, \mathrm{O}, \mathrm{Na}, \mathrm{Mg}, \mathrm{Al}, \mathrm{Si}, \mathrm{S}$, and $\mathrm{Ca}$, and the ratio of $S$ to $C$ is close to 1:1. However, the contents of $S$ and $C a$ are very small (about $1 \%$ ) and close to that of $\mathrm{Mg}(0.57 \%)$. Thus, we speculate that the mineral is the reduction form of ankerite.

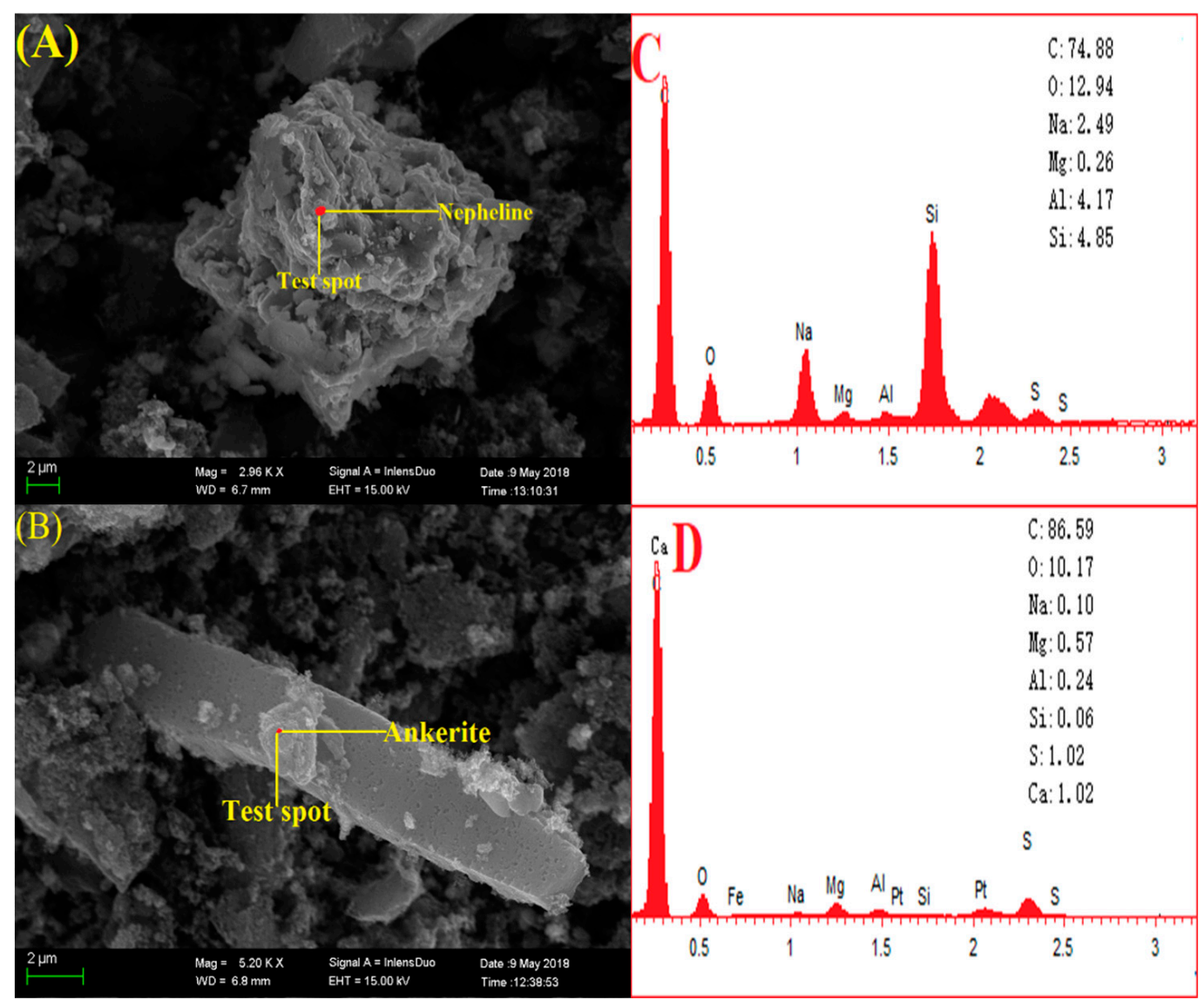

Figure 5. SEM-EDS micrographs of minerals in ashes obtained from different reduction temperatures (secondary electron images). (A) Nepheline $\left(900{ }^{\circ} \mathrm{C}\right)$; (B) ankerite $\left(1000{ }^{\circ} \mathrm{C}\right)$; (C) EDS of nepheline; (D) EDS of ankerite.

As exhibited in the SEM image in Figure 6A, irregular blocky particles appear in the $1100{ }^{\circ} \mathrm{C}$ reduction ash. After EDS analysis, it can be concluded that the particle is magnetite, which is consistent with the XRD analysis. Moreover, a globular mineral phase appears in Figure 6B, after the EDS analysis, the content of $\mathrm{O}, \mathrm{Mg}, \mathrm{Na}$, and $\mathrm{S}$ elements is relatively high, the content of $\mathrm{Si}$ is relatively low, and the ratio of $\mathrm{O}$ and $\mathrm{Mg}$ is close to 1:1. Thus, we can speculate that the mineral is periclase. 


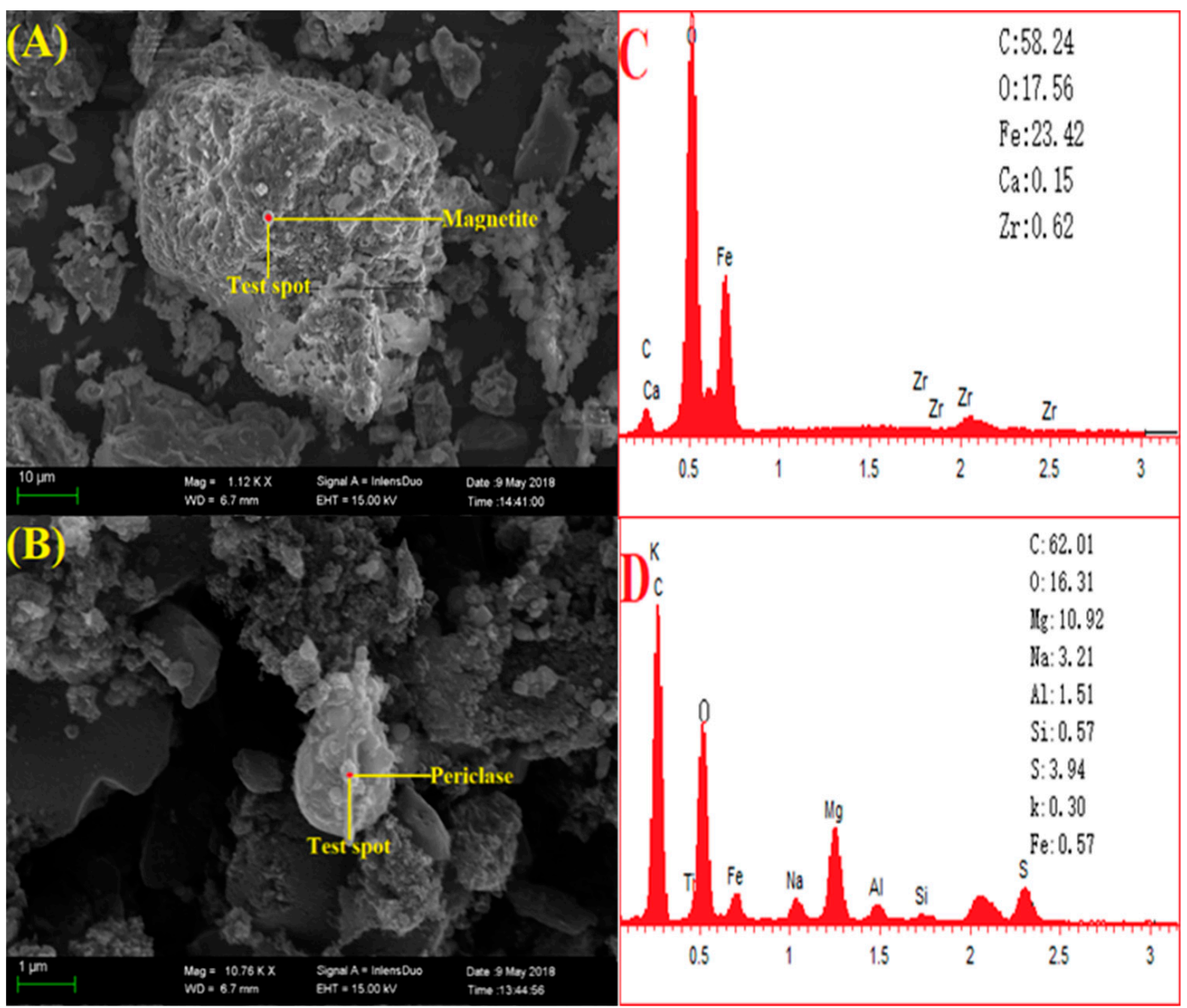

Figure 6. SEM-EDS micrographs of minerals in ashes obtained from different reduction temperatures (secondary electron images). (A) Magnetite $\left(1100^{\circ} \mathrm{C}\right)$; (B) periclase $\left(1100^{\circ} \mathrm{C}\right)$; (C) EDS of magnetite; (D) EDS of periclase.

\subsection{Mineral Transformation during Residual-Coke Oxidation Process}

The XRD patterns of the ashes obtained from different oxidation temperatures are exhibited in Figure 7. The gehlenite $\left(\mathrm{Ca}_{2} \mathrm{Al}_{2} \mathrm{SiO}_{7}\right)$ is detected in the oxidized ash at $1100{ }^{\circ} \mathrm{C}$ and is formed in large quantities at $1200{ }^{\circ} \mathrm{C}$; its content decreases by $1300{ }^{\circ} \mathrm{C}$. As the temperature rises to $1400{ }^{\circ} \mathrm{C}$, the gehlenite is transformed into anorthite $\left(\mathrm{CaAl}_{2} \mathrm{Si}_{2} \mathrm{O}_{8}\right)$. With the further progress of the reaction, anorthite will co-melt with iron-bearing minerals above $1500{ }^{\circ} \mathrm{C}$. The magnetite $\left(\mathrm{Fe}_{3} \mathrm{O}_{4}\right)$ and hematite $\left(\mathrm{Fe}_{2} \mathrm{O}_{3}\right)$ are detected in the $1100{ }^{\circ} \mathrm{C}$ oxidation ash. Magnetite is completely converted to hematite when the temperature increases to $1200{ }^{\circ} \mathrm{C}$ [13]. The reason for this change could be explained as follows: $\mathrm{Fe}^{2+}$ that is present in the form of magnetite reacts with the oxidizing agent, generating $\mathrm{Fe}^{3+}$ existing hematite at $1200^{\circ} \mathrm{C}$, and then the hematite is converted to augite and finally completely transformed into augite at $1400{ }^{\circ} \mathrm{C}$. When the temperature reaches $1500{ }^{\circ} \mathrm{C}$, augite $\left(\mathrm{CaFeSi}_{2} \mathrm{O}_{6}\right)$ is eventually transformed into thermodynamically stable cordierite $\left(\mathrm{Fe}_{2} \mathrm{Al}_{4} \mathrm{Si}_{5} \mathrm{O}_{18}\right)$ [41]. The reactions are as follows.

$$
\begin{aligned}
2 / 3 \mathrm{Fe}_{3} \mathrm{O}_{4}+1 / 6 \mathrm{O}_{2} & \rightarrow \mathrm{Fe}_{2} \mathrm{O}_{3} \\
\mathrm{Fe}_{2} \mathrm{O}_{3}+2 \mathrm{CaSi}_{2} \mathrm{O}_{5} & \rightarrow 2 \mathrm{CaFeSi}_{2} \mathrm{O}_{6} \\
2 \mathrm{CaFeSi}_{2} \mathrm{O}_{6}+2 \mathrm{Al}_{2} \mathrm{O}_{3}+\mathrm{SiO}_{2} & \rightarrow \mathrm{Fe}_{2} \mathrm{Al}_{4} \mathrm{Si}_{5} \mathrm{O}_{18}+2 \mathrm{CaO}
\end{aligned}
$$




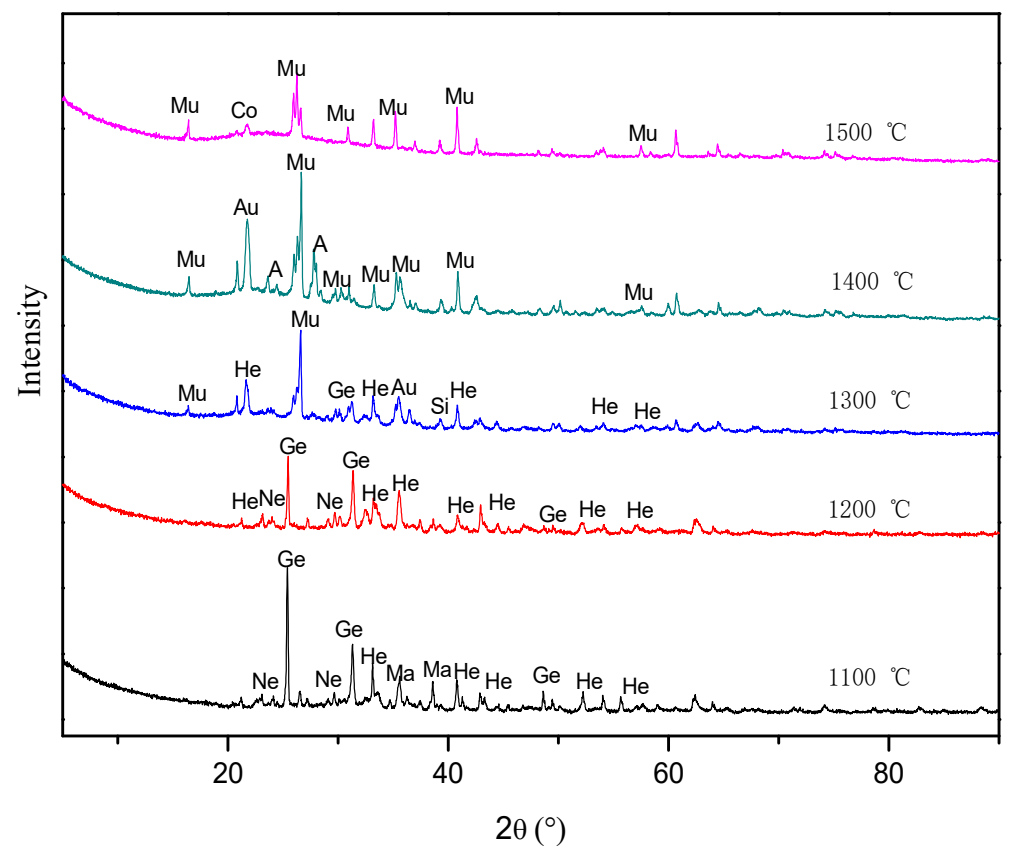

Figure 7. XRD patterns of the ashes obtained from different oxidation temperatures. $\mathrm{He}$-hematite; $\mathrm{Ma}$-magnetite; $\mathrm{Mu}$-mullite; $\mathrm{A}$-anorthite; $\mathrm{Au}$-augite; $\mathrm{Si}$ - sillimanite; $\mathrm{Co}$-cordierite; $\mathrm{Ge}$-gehlenite; $\mathrm{Ne}$-nepheline.

Sillimanite $\left(\mathrm{Al}_{2} \mathrm{SiO}_{5}\right)$ is detected at $1200{ }^{\circ} \mathrm{C}$ and is present in great quantities at $1300{ }^{\circ} \mathrm{C}$. Above $1300{ }^{\circ} \mathrm{C}$, the sillimanite disappears, but mullite $\left(\mathrm{Al}_{6} \mathrm{Si}_{2} \mathrm{O}_{13}\right)$ is formed. The decomposition product $\left(\mathrm{Al}_{2} \mathrm{O}_{3}\right)$ of illite can react with $\mathrm{SiO}_{2}$ to produce sillimanite. With the temperature rises, sillimanite is transformed into mullite.

As shown in Table 4, it can be inferred that the content of hematite gradually decreases as the oxidation temperature increases; trending from $23 \%$ hematite in the $1100{ }^{\circ} \mathrm{C}$ oxidation ash to $8 \%$ hematite at $1300{ }^{\circ} \mathrm{C}$. Mullite formed at $1300{ }^{\circ} \mathrm{C}$ and its content gradually increases from $29 \%\left(1300{ }^{\circ} \mathrm{C}\right)$ to $60 \%\left(1500{ }^{\circ} \mathrm{C}\right)$. The gehlenite formed in large quantities at $120{ }^{\circ} \mathrm{C}$, which is completely converted to anorthite when the temperature reaches $1400^{\circ} \mathrm{C}$. The reactions are as follows.

$$
\begin{gathered}
2 \mathrm{CaO}+\mathrm{Al}_{2} \mathrm{O}_{3}+\mathrm{SiO}_{2} \rightarrow 2 \mathrm{CaO} \cdot \mathrm{Al}_{2} \mathrm{O}_{3} \cdot \mathrm{SiO}_{2} \\
\mathrm{CaO}+\mathrm{Al}_{2} \mathrm{O}_{3}+2 \mathrm{SiO}_{2} \rightarrow \mathrm{CaO} \cdot \mathrm{Al}_{2} \mathrm{O}_{3} \cdot 2 \mathrm{SiO}_{2} \\
2 \mathrm{CaO} \cdot \mathrm{Al}_{2} \mathrm{O}_{3} \cdot \mathrm{SiO}_{2}+\mathrm{Al}_{2} \mathrm{O}_{3}+3 \mathrm{SiO}_{2} \rightarrow 2\left(\mathrm{CaO} \cdot \mathrm{Al}_{2} \mathrm{O}_{3} \cdot 2 \mathrm{SiO}_{2}\right)
\end{gathered}
$$

Table 4. Mineral composition of oxidation ash by XRD analysis and Siroquant.

\begin{tabular}{cccccc}
\hline Mineral Composition & $\mathbf{1 1 0 0}{ }^{\circ} \mathbf{C}$ & $\mathbf{1 2 0 0}{ }^{\circ} \mathbf{C}$ & $\mathbf{1 3 0 0}{ }^{\circ} \mathbf{C}$ & $\mathbf{1 4 0 0}{ }^{\circ} \mathbf{C}$ & $\mathbf{1 5 0 0}{ }^{\circ} \mathbf{C}$ \\
\hline Magnetite & $7 \%$ & - & - & - & - \\
Hematite & $23 \%$ & $20 \%$ & $8 \%$ & - & - \\
Gehlenite & $43 \%$ & $57 \%$ & $11 \%$ & - & - \\
Nepheline & $27 \%$ & $23 \%$ & - & - & - \\
Augite & - & - & $22 \%$ & $8 \%$ & - \\
Sillimanite & - & - & $23 \%$ & - & - \\
Anorthite & - & - & - & $31 \%$ & - \\
Cordierite & - & - & - & - & $8 \%$ \\
Mullite & - & - & $29 \%$ & $40 \%$ & $60 \%$ \\
Amorphous & - & - & $7 \%$ & $21 \%$ & $32 \%$ \\
\hline
\end{tabular}


As exhibited in the SEM image in Figure 8B, the gehlenite is present in the $1100{ }^{\circ} \mathrm{C}$ oxidation ash of the Zhundong coal. Since the thermodynamic properties of anorthite are more stable than that of gehlenite, when the temperature increases to $1400^{\circ} \mathrm{C}$, gehlenite is converted to anorthite (Figure $8 \mathrm{~A}$ ).

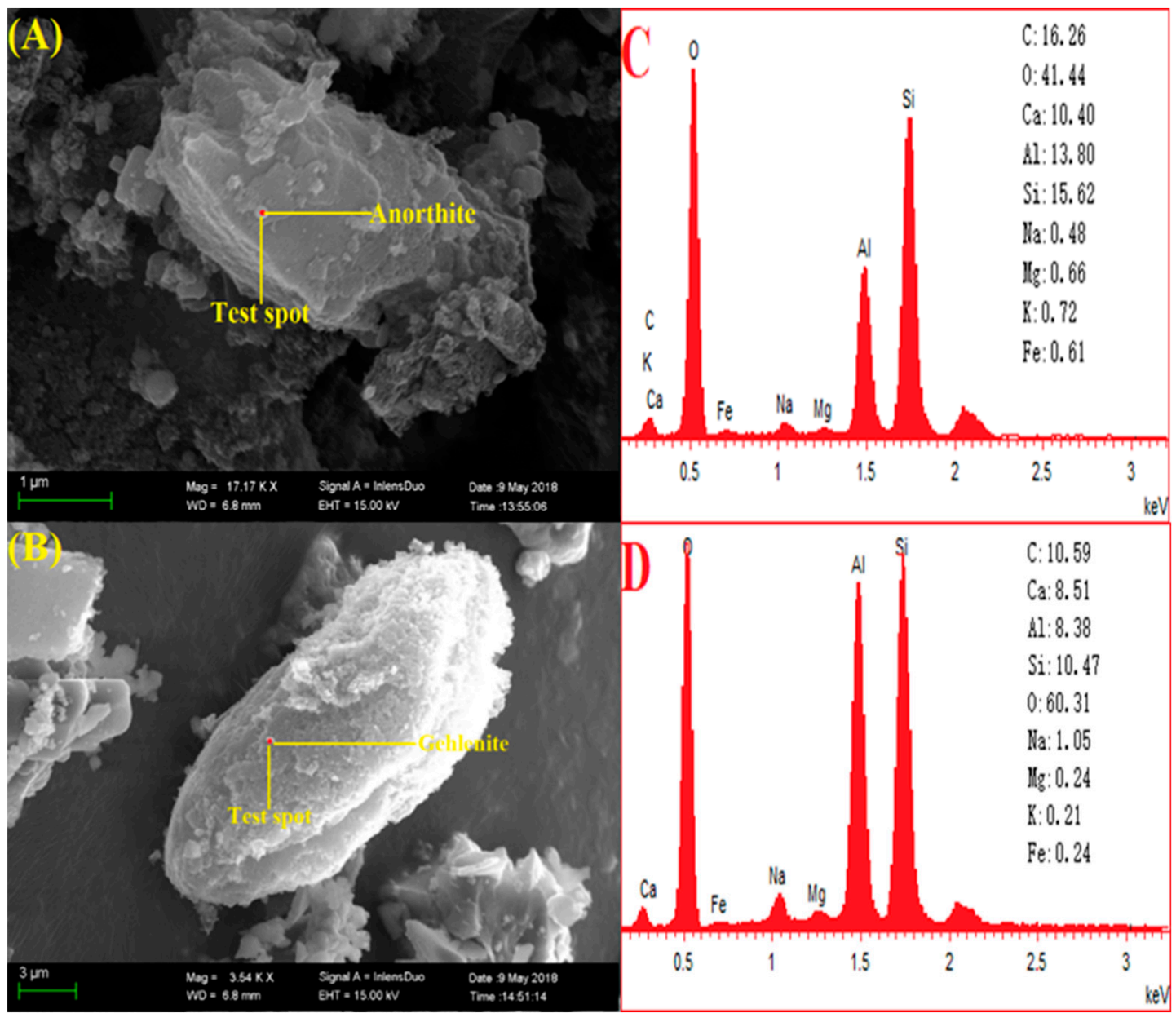

Figure 8. SEM-EDS micrographs of minerals in ashes obtained from different oxidation temperatures (secondary electron images). (A) Anorthite $\left(1400^{\circ} \mathrm{C}\right)$; (B) gehlenite $\left(1100^{\circ} \mathrm{C}\right)$; (C) EDS of anorthite; (D) EDS of gehlenite.

The sequential transformation of calcium-bearing minerals with increasing temperature are exhibited in Figure 9. The calcium-bearing mineral is gradually converted from gypsum $\left(\mathrm{CaSO}_{4} \cdot 2 \mathrm{H}_{2} \mathrm{O}\right)$ in the raw coal into anhydrite $\left(\mathrm{CaSO}_{4}\right)$ during the pyrolysis process. In the reduction stage, anhydrite reacts with the reducing gas $(\mathrm{CO})$ to produce oldhamite $(\mathrm{CaS})$, and the oldhamite is stably present in the reduction ash. During the oxidation process, oldhamite is first transformed into $\mathrm{CaSO}_{4}$, and then $\mathrm{CaSO}_{4}$ is converted into $\mathrm{CaO}$. Finally, $\mathrm{CaO}$ reacts with $\mathrm{Al}_{2} \mathrm{O}_{3}$ and $\mathrm{SiO}_{2}$ to produce gehlenite $\left(\mathrm{Ca}_{2} \mathrm{Al}_{2} \mathrm{SiO}_{7}\right)$ at $1100{ }^{\circ} \mathrm{C}$ [42-45]. When the temperature increases to $1400{ }^{\circ} \mathrm{C}$, gehlenite is transformed to the thermodynamically stable anorthite $\left(\mathrm{CaAl}_{2} \mathrm{Si}_{2} \mathrm{O}_{8}\right)$. With the further progress of the reaction, anorthite will co-melt with iron-bearing minerals above $1500{ }^{\circ} \mathrm{C}$. 


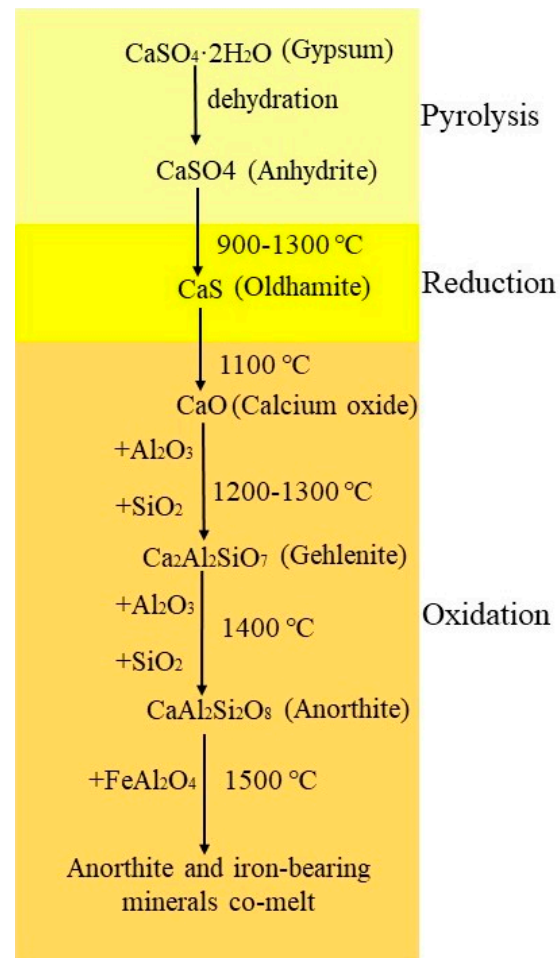

Figure 9. Sequential transformation of calcium-bearing minerals in underground coal gasification (UCG) process.

\subsection{Calculation of Phase Diagrams}

As exhibited in Figure 10, when the total of $\mathrm{SiO}_{2}$ and $\mathrm{Al}_{2} \mathrm{O}_{3}$ content is about 0.8 , mullite and quartz are formed in great quantities. The calcium-bearing mineral is stably present in the form of oldhamite. The phase diagram of $\mathrm{SiO}_{2}-\mathrm{Al}_{2} \mathrm{O}_{3}-\mathrm{CaO}$ (Figure 11) shows that Gehlenite and anorthite are the main calcium-bearing minerals that could be observed when the mole fraction of $\mathrm{CaO}$ is 0.4 . Gehlenite begins to form at $1277^{\circ} \mathrm{C}$ and is converted into anorthite when the temperature rises to 1426 ${ }^{\circ} \mathrm{C}$. The mineral phase gradually moves from mullite to anorthite with the increase of $\mathrm{CaO}$ and the melting temperature decreases [46-48]. However, when the mole fraction of $\mathrm{CaO}$ increases, the main minerals in the ash are corundum and cristobalite, causing an increase of the melting point. Since $\mathrm{CaO}$ is an alkaline earth metal oxide, which easily reacts with $\mathrm{SiO}_{2}$ to form silicate minerals $\left(\mathrm{Ca}_{2} \mathrm{SiO}_{4}\right.$, $\left.\mathrm{Ca}_{3} \mathrm{Si}_{2} \mathrm{O}_{7}, \mathrm{CaSiO}_{3}\right)$; minerals with lower melting points. When the mole fraction of $\mathrm{CaO}$ is less than 0.7 , the addition of $\mathrm{CaO}$ acts to lower the ash melting point $[49,50]$. When the mole fraction of $\mathrm{CaO}$ is higher than 0.7 , the ash melting temperature no longer decrease, whereas it rises slightly due to the high melting point of $\mathrm{CaO}$. 


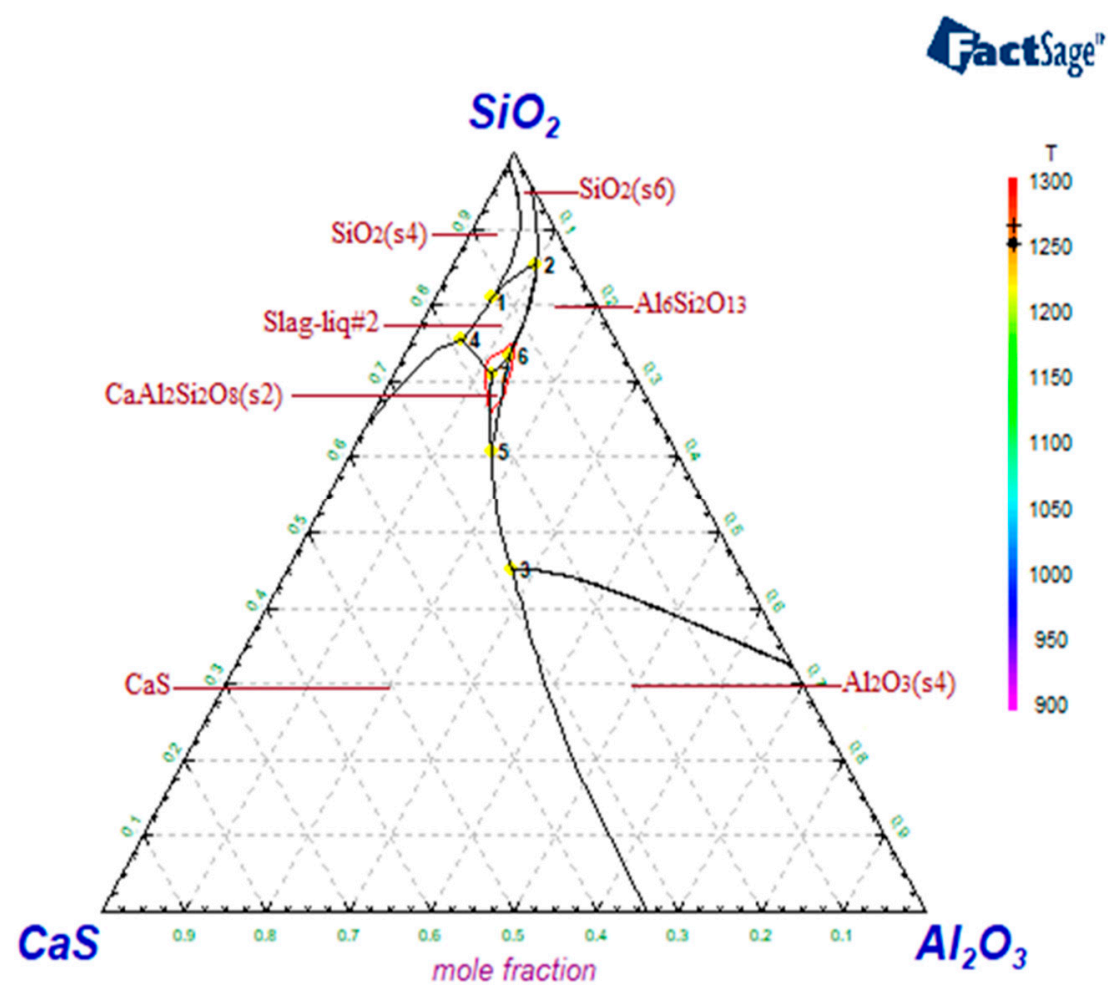

Figure 10. Ternary phase diagram of $\mathrm{Al}_{2} \mathrm{O}_{3}-\mathrm{SiO}_{2}-\mathrm{CaS}$ system.

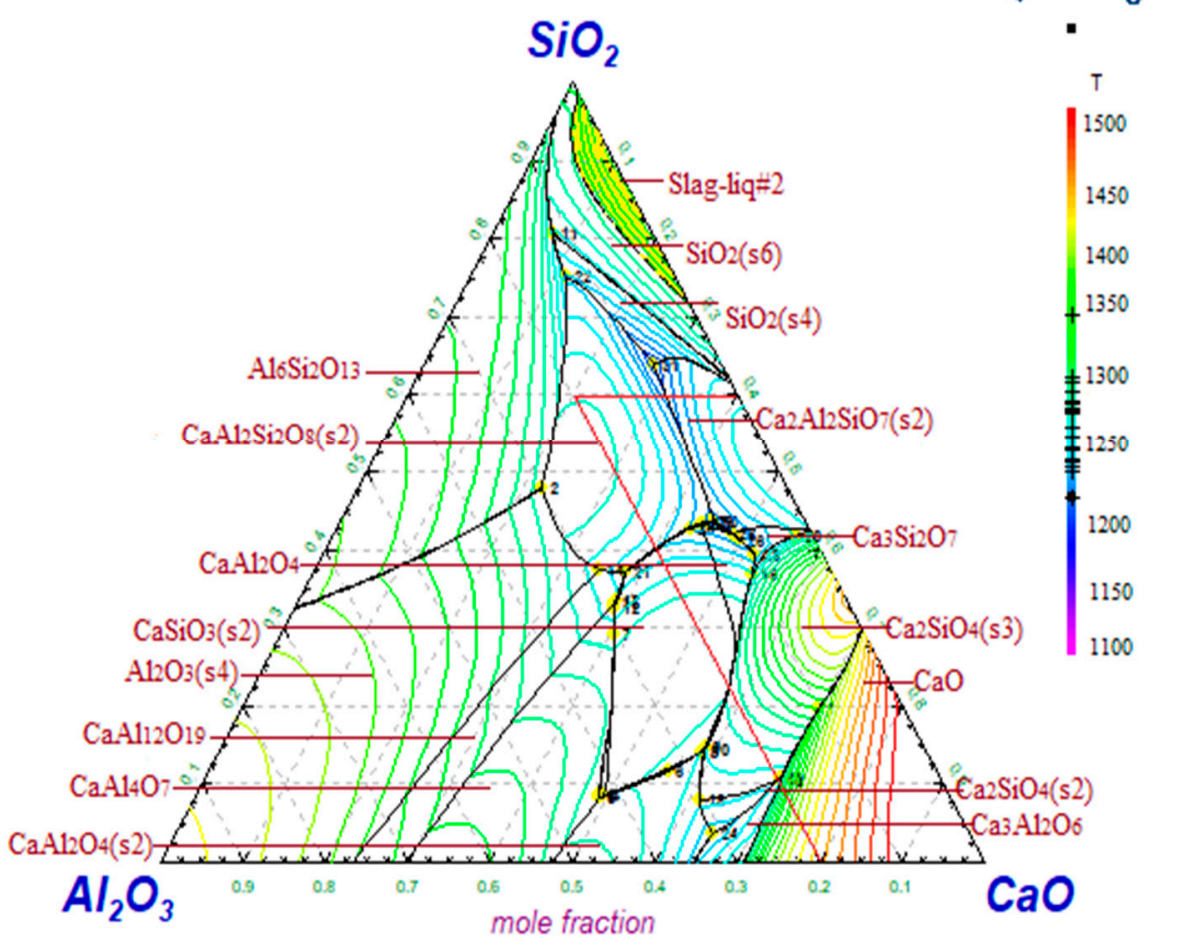

Figure 11. Ternary phase diagram of $\mathrm{Al}_{2} \mathrm{O}_{3}-\mathrm{SiO}_{2}-\mathrm{CaO}$ system.

\subsection{FactSage Equilib Calculations}

To further illustrate the mineral transformation at high temperatures, the equilibrium for the entire ash system under reducing and oxidizing atmospheres were calculated by Equilib. As shown in Figure 12a, $\mathrm{NaAlSiO}_{4}, \mathrm{CaCO}_{3}, \mathrm{MgO}, \mathrm{KAlSi}_{3} \mathrm{O}_{8}$, and $\mathrm{CaO}$ are present in the reduction ash. The content 
of calcite $\left(\mathrm{CaCO}_{3}\right)$ and lime $(\mathrm{CaO})$ gradually decreases in the temperature ranging from 900 to $1100{ }^{\circ} \mathrm{C}$. As temperature increasing, the content of $\mathrm{NaAlSiO}_{4}$ decreases dramatically and it disappears at $1300^{\circ} \mathrm{C}$. The content of $\mathrm{MgO}$ remained basically unchanged in the range of $900-1200^{\circ} \mathrm{C}$. The oldhamite $(\mathrm{CaS})$ does not appear in the reduction ash because of its low content, which is inconsistent with the XRD results. As exhibited in Figure 12b, the major minerals formed in the oxidation ash are $\mathrm{Ca}_{2} \mathrm{Al}_{2} \mathrm{SiO}_{7}$, $\mathrm{Fe}_{2} \mathrm{Al}_{4} \mathrm{Si}_{5} \mathrm{O}_{18}, \mathrm{NaAlSiO}_{4}, \mathrm{Al}_{6} \mathrm{Si}_{2} \mathrm{O}_{13}$, and $\mathrm{Fe}_{2} \mathrm{O}_{3}$. Mullite increases with the rise of oxidation temperature. The content of gehlenite decreases in the temperature range of $1100-1300{ }^{\circ} \mathrm{C}$. Moreover, $\mathrm{NaAlSiO}_{4}$ disappears in the oxidation ash at $1300^{\circ} \mathrm{C}$, which is consistent with the experimental results.
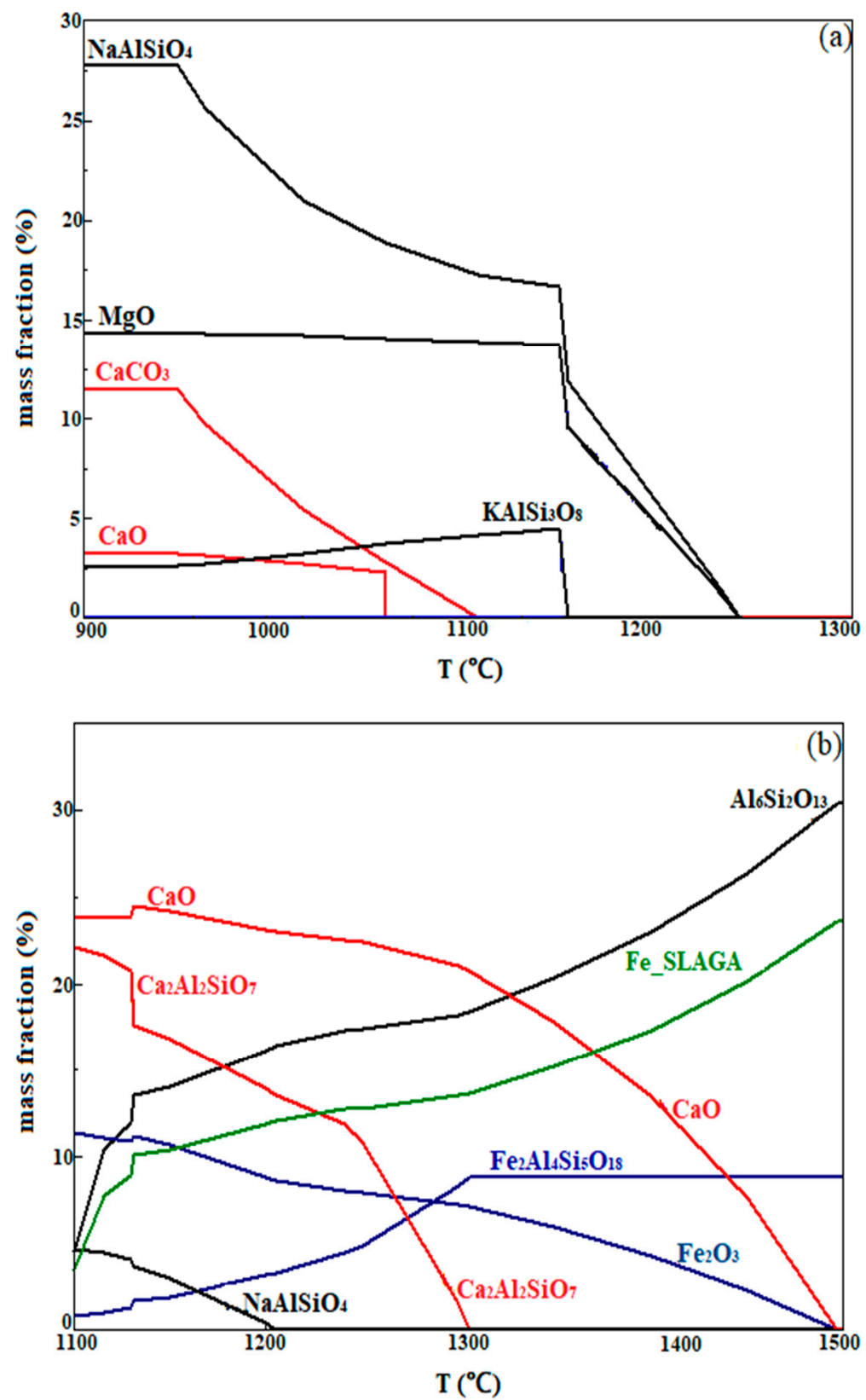

Figure 12. Major mineral transformation at high temperatures calculated by FactSage. (a) Reduction stage; (b) oxidation stage.

\subsection{Reaction Mechanism of Minerals}

Table 5 shows the possible reactions between minerals in coal ash at high temperature. FactSage is used to calculate the $\Delta \mathrm{G}$ and $\Delta \mathrm{H}$ of the reactions. The smaller the $\Delta \mathrm{G}$ of the reactions, indicating that 
the reactions are easier to proceed. Thus, the degree of the reaction can be judged according to the $\Delta \mathrm{G}$, and the reaction mechanism can be inferred. The $\Delta \mathrm{G}$ of the formation reaction of mullite, anorthite, and gehlenite decreases gradually with the increase of temperature, indicating that these minerals are easier to form. While the $\Delta \mathrm{G}$ of calcium silicate $\left(\mathrm{CaSiO}_{3}\right)$ formation reaction increases gradually with the temperature rise, indicating that the formation of $\mathrm{CaSiO}_{3}$ is inhibited. At the same reaction temperature, $\Delta \mathrm{G}$ of the formation reaction of anorthite, gehlenite, and nepheline is much smaller than that of mullite. Therefore, the formation of mullite and wollastonite can be effectively inhibited when the content of $\mathrm{CaO}$ in coal ash increases. At the same time, nepheline, anorthite, and gehlenite have lower melting point, which reduces the melting temperature of coal ash.

Table 5. $\Delta \mathrm{G}$ and $\Delta \mathrm{H}$ of mineral reaction in coal ash.

\begin{tabular}{|c|c|c|c|c|c|c|c|c|c|c|}
\hline \multirow{2}{*}{ Reaction } & \multicolumn{5}{|c|}{$\Delta \mathbf{G} / \mathbf{K J}$} & \multicolumn{5}{|c|}{$\triangle \mathbf{H} / \mathbf{K J}$} \\
\hline & $1100^{\circ} \mathrm{C}$ & $1200^{\circ} \mathrm{C}$ & $1300^{\circ} \mathrm{C}$ & $1400^{\circ} \mathrm{C}$ & $1500^{\circ} \mathrm{C}$ & $1100^{\circ} \mathrm{C}$ & $1200^{\circ} \mathrm{C}$ & $1300^{\circ} \mathrm{C}$ & $1400^{\circ} \mathrm{C}$ & $1500{ }^{\circ} \mathrm{C}$ \\
\hline $\begin{array}{c}3 \mathrm{Al}_{2} \mathrm{O}_{3}+2 \mathrm{SiO}_{2} \rightarrow \\
\mathrm{Al}_{6} \mathrm{Si}_{2} \mathrm{O}_{13}\end{array}$ & -18.9 & -21 & -25 & -28 & -31 & 22.59 & 22.6 & 22.7 & 22.8 & 22.82 \\
\hline $\begin{array}{c}\mathrm{CaO}+\mathrm{Al}_{2} \mathrm{O}_{3}+2 \mathrm{SiO}_{2} \rightarrow \\
\mathrm{CaAl}_{2} \mathrm{Si}_{2} \mathrm{O}_{8}\end{array}$ & -134 & -136 & -139 & -141 & -144 & -101 & -100 & -99 & -98 & -96 \\
\hline $\begin{array}{c}2 \mathrm{CaO}+\mathrm{Al}_{2} \mathrm{O}_{3}+\mathrm{SiO}_{2} \rightarrow \\
\mathrm{Ca}_{2} \mathrm{Al}_{2} \mathrm{SiO}_{7}\end{array}$ & -166 & -170 & -173 & -176 & -179 & -124 & -125 & -126 & -127 & -128 \\
\hline $\begin{array}{c}\mathrm{Na} 2 \mathrm{O}+\mathrm{Al}_{2} \mathrm{O}_{3}+2 \mathrm{SiO}_{2} \\
\rightarrow 2 \mathrm{NaAlSiO}_{4}\end{array}$ & -360 & -363 & -365 & -368 & -370 & -322 & -323 & -324 & -325 & -326 \\
\hline
\end{tabular}

\section{Conclusions}

In this paper, the sequential transformation behavior of calcium-bearing minerals during underground coal gasification was investigated. Based on the experimental data, the conclusions can be summarized as follows.

(1) During the pyrolysis process, the calcium-bearing mineral in the coal is transformed from gypsum $\left(\mathrm{CaSO}_{4} \cdot 2 \mathrm{H}_{2} \mathrm{O}\right)$ to anhydrite $\left(\mathrm{CaSO}_{4}\right)$.

(2) During the reduction process, the main minerals found in the ash in the temperature range 900-1300 ${ }^{\circ} \mathrm{C}$ include magnetite $\left(\mathrm{Fe}_{3} \mathrm{O}_{4}\right)$, oldhamite $(\mathrm{CaS})$, periclase $(\mathrm{MgO})$, and nepheline $\left(\mathrm{NaAlSiO}_{4}\right)$. The anhydrite reacts with the reducing gas $(\mathrm{CO})$ to produce oldhamite (CaS), and the oldhamite is stably present in the reduced ash.

(3) During the oxidation stage, the typical minerals in the ash include gehlenite $\left(\mathrm{Ca}_{2} \mathrm{Al}_{2} \mathrm{SiO}_{7}\right)$, anorthite $\left(\mathrm{CaAl}_{2} \mathrm{Si}_{2} \mathrm{O}_{8}\right)$, hematite $\left(\mathrm{Fe}_{2} \mathrm{O}_{3}\right)$, augite $\left(\mathrm{FeSi}_{2} \mathrm{O}_{6}\right)$, mullite $\left(\mathrm{Al}_{6} \mathrm{Si}_{2} \mathrm{O}_{13}\right)$, and cordierite $\left(\mathrm{Fe}_{2} \mathrm{Al}_{4} \mathrm{Si}_{5} \mathrm{O}_{18}\right)$. During the oxidation process, oldhamite is first transformed into $\mathrm{CaSO}_{4}$, and then $\mathrm{CaSO}_{4}$ is converted into $\mathrm{CaO}$. Finally, $\mathrm{CaO}$ reacts with $\mathrm{Al}_{2} \mathrm{O}_{3}$ and $\mathrm{SiO}_{2}$ to produce gehlenite $\left(\mathrm{Ca}_{2} \mathrm{Al}_{2} \mathrm{SiO}_{7}\right)$ above $1100{ }^{\circ} \mathrm{C}$. When the temperature increases to $1400{ }^{\circ} \mathrm{C}$, gehlenite is converted to the thermodynamically stable anorthite $\left(\mathrm{CaAl}_{2} \mathrm{Si}_{2} \mathrm{O}_{8}\right)$. As the temperature further increases, anorthite will co-melt with iron-bearing minerals above $1500{ }^{\circ} \mathrm{C}$.

(4) FactSage equilibrium calculations indicate that gehlenite and anorthite are the main minerals when the mole fraction of $\mathrm{CaO}$ is 0.4 . Gehlenite begins to form at $1277^{\circ} \mathrm{C}$, and gehlenite is converted into anorthite when the temperature rises to $1426^{\circ} \mathrm{C}$.

Author Contributions: S.L. conceived of and designed the experiments. W.M. performed the experiments, performed the X-ray diffraction (XRD) determination and thermodynamic simulation, observed the slag using SEM-EDS, and analyzed the data. All authors participated in writing the manuscript.

Funding: This research was funded by the Natural Science Foundation of China, grant number 51476185 and the APC was funded by the Natural Science Foundation of China, grant number 51476185.

Acknowledgments: The authors wish to thank Editor Shifeng Dai for handing this manuscript.

Conflicts of Interest: The authors declare no conflict of interest. 


\section{References}

1. Finkelman, R.B.; Dai, S.; French, D. The importance of minerals in coal as the hosts of chemical elements: A review. Int. J. Coal Geol. 2019, 212, 103251. [CrossRef]

2. Van Dyk, J.C.; Benson, S.A.; Laumb, M.L.; Waanders, B. Coal and coal ash characteristics to understand mineral transformations and slag formation. Fuel 2009, 88, 1057-1063. [CrossRef]

3. Winnefeld, F.; Leemann, A.; Lucuk, M.; Svoboda, P.; Neuroth, M. Assessment of phase formation in alkali activated low and high calcium fly ashes in building materials. Constr. Build. Mater. 2010, 24, 1086-1093. [CrossRef]

4. Ding, L.; Gao, Y.; Li, X.; Wang, W.; Xue, Y.; Zhu, X.; Xu, K.; Hu, H.; Luo, G.; Naruse, I. A novel $\mathrm{CO}_{2}$-water leaching method for AAEM removal from Zhundong coal. Fuel 2019, 237, 786-792. [CrossRef]

5. Li, G.; Li, S.; Huang, Q.; Yao, Q. Fine particulate formation and ash deposition during pulverized coal combustion of high-sodium lignite in a down-fired furnace. Fuel 2015, 143, 430-437. [CrossRef]

6. Yang, Y.; Lin, X.; Chen, X.; Wang, Y.; Gao, L.; Chen, L. The formation of deposits and their evolutionary characteristics during pressurized gasification of Zhundong coal char. Fuel 2018, 224, 469-480. [CrossRef]

7. Yang, Y.; Lin, X.; Chen, X.; Guo, W.; Wang, Y.; Zhang, J.; Kawa, O. Investigation on the effects of different forms of sodium, chlorine and sulphur and various pretreatment methods on the deposition characteristics of Na species during pyrolysis of a Na-rich coal. Fuel 2018, 234, 872-885. [CrossRef]

8. He, Y.; Whiddon, R.; Wang, Z.; Liu, Y.; Zhu, Y.; Liu, J.; Cen, K. Inhibition of Sodium Release from Zhundong Coal via the Addition of Mineral Additives: Online Combustion Measurement with Laser-Induced Breakdown Spectroscopy (LIBS). Energy Fuels 2017, 31, 1082-1090. [CrossRef]

9. Weimer, T.; Berger, R.; Hawthorne, C.; Abanades, J.C. Lime enhanced gasification of solid fuels: Examination of a process for simultaneous hydrogen production and $\mathrm{CO}_{2}$ capture. Fuel 2008, 87, 1678-1686. [CrossRef]

10. Zhao, Y.; Zhang, J.; Tian, C.; Li, H.; Shao, X.; Zheng, C. Mineralogy and chemical composition of high-calcium fly ashes and density fractions from a coal-fired power plant in China. Energy Fuels 2010, 24, 834-843. [CrossRef]

11. Liu, S.; Qi, C.; Zhang, S.; Deng, Y. Minerals in the Ash and Slag from Oxygen-Enriched Underground Coal Gasification. Minerals 2016, 6, 27. [CrossRef]

12. Khan, M.M.; Mmbaga, J.P.; Shirazi, A.S.; Trivedi, J.; Liu, Q.; Gupta, R. Modelling underground coal gasification-A review. Energies 2015, 8, 12603-12668. [CrossRef]

13. Liu, S.; Ma, W.; French, D.; Tuo, K.; Mei, X. Sequential mineral transformation during underground coal gasification with the presence of coal partings. Int. J. Coal Geol. 2019, 208, 1-11. [CrossRef]

14. Ji, J.; Cheng, L.; Liu, Y.; Wei, Y.; Nie, L. Investigation on Sodium Fate for High Alkali Coal during Circulating Fluidized Bed Combustion. Energy Fuels 2019, 33, 916-926. [CrossRef]

15. Kosminski, A.; Ross, D.P.; Agnew, J.B. Transformations of sodium during gasification of low-rank coal. Fuel Process. Technol. 2006, 87, 943-952. [CrossRef]

16. Kosminski, A.; Ross, D.P.; Agnew, J.B. Reactions between sodium and kaolin during gasification of a low-rank coal. Fuel Process. Technol. 2006, 87, 1051-1062. [CrossRef]

17. Li, G.; Wang, C.; Yan, Y.; Jin, X.; Liu, Y.; Che, D. Release and transformation of sodium during combustion of Zhundong coals. J. Energy Inst. 2016, 89, 48-56. [CrossRef]

18. Zhang, H.; Guo, X.; Zhu, Z. Effect of temperature on gasification performance and sodium transformation of Zhundong coal. Fuel 2017, 189, 301-311. [CrossRef]

19. Yang, S.; Song, G.; Na, Y.; Song, W.; Qi, X.; Yang, Z. Transformation characteristics of Na and K in high alkali residual carbon during circulating fluidized bed combustion. J. Energy Inst. 2019, 92, 62-73. [CrossRef]

20. Gao, Y.; Ding, L.; Li, X.; Wang, W.; Xue, Y.; Zhu, X.; Hu, H.; Luo, G.; Naruse, I.; Bai, Z. Na \& Ca removal from Zhundong coal by a novel $\mathrm{CO}_{2}$-water leaching method and the ashing behavior of the leached coal. Fuel 2017, 210, 8-14.

21. Zhou, J.; Zhuang, X.; Alastuey, A.; Querol, X.; Li, J. Geochemistry and mineralogy of coal in the recently explored Zhundong large coal field in the Junggar basin, Xinjiang province, China. Int. J. Coal Geol. 2010, 82, 51-67. [CrossRef]

22. ASTM International. ASTM Standard D3173-11. Test Method for Moisture in the Analysis Sample of Coal and Coke; ASTM International: West Conshohocken, PA, USA, 2011. 
23. ASTM International. ASTM Standard D3175-11. Test Method for Volatile Matter in the Analysis Sample of Coal and Coke; ASTM International: West Conshohocken, PA, USA, 2011.

24. ASTM International. ASTM Standard D3174-11. Annual Book of ASTM Standards. Test Method for Ash in the Analysis Sample of Coal and Coke; ASTM International: West Conshohocken, PA, USA, 2011.

25. ASTM International. ASTM Standard D3177-02. Test Methods for Total Sulfur in the Analysis Sample of Coal and Coke; Reapproved 2007; ASTM International: West Conshohocken, PA, USA, 2002.

26. Duan, P.; Wang, W.; Sang, S.; Qian, F.; Shao, P.; Zhao, X. Partitioning of hazardous elements during preparation of high-uranium coal from Rongyang, Guizhou, China. J. Geochem. Explor. 2018, 185, 81-92. [CrossRef]

27. Van Dyk, J.C.; Keyser, M.J. Influence of discard mineral matter on slag-liquid formation and ash melting properties of coal-A FACTSAGE ${ }^{\mathrm{TM}}$ simulation study. Fuel 2014, 116, 834-840. [CrossRef]

28. Liu, X.; Yu, G.; Xu, J.; Liang, Q.; Liu, H. Viscosity fluctuation behaviors of coal ash slags with high content of calcium and low content of silicon. Fuel Process. Technol. 2017, 158, 115-122. [CrossRef]

29. Wang, Y.; Jin, J.; Liu, D.; Yang, H.; Li, S. Understanding Ash Deposition for the Combustion of Zhundong Coal: Focusing on Different Additives Effects. Energy Fuels 2018, 6, 7103-7111. [CrossRef]

30. Chen, X.D.; Kong, L.X.; Bai, J.; Bai, Z.Q.; Li, W. Study on fusibility of coal ash rich in sodium and sulfur by synthetic ash under different atmospheres. Fuel 2017, 202, 175-183. [CrossRef]

31. Dai, B.Q.; Wu, X.; De Girolamo, A.; Zhang, L. Inhibition of lignite ash slagging and fouling upon the use of a silica-based additive in an industrial pulverised coal-fired boiler. Part 1. Changes on the properties of ash deposits along the furnace. Fuel 2015, 139, 720-732. [CrossRef]

32. Xu, J.; Yu, D.; Fan, B.; Zeng, X.; Lv, W.; Chen, J. Characterization of ash particles from co-combustion with a Zhundong coal for understanding ash deposition behavior. Energy Fuels 2014, 28, 678-684. [CrossRef]

33. Zhang, X.; Liu, H.; Xing, H.; Li, H.; Hu, H.; Li, A.; Yao, H. Improved sodium adsorption by modified kaolinite at high temperature using intercalation-exfoliation method. Fuel 2017, 191, 198-203. [CrossRef]

34. Wang, X.; Zhang, M.; Zhang, W.; Wang, J.; Zhou, Y.; Song, X.; Li, T.; Li, X.; Liu, H.; Zhao, L. Occurrence and origins of minerals in mixed-layer illite/smectite-rich coals of the Late Permian age from the Changxing Mine, eastern Yunnan, China. Int. J. Coal Geol. 2012, 102, 26-34. [CrossRef]

35. Dai, S.; Zou, J.; Jiang, Y.; Ward, C.R.; Wang, X.; Li, T.; Xue, W.; Liu, S.; Tian, H.; Sun, X. Mineralogical and geochemical compositions of the Pennsylvanian coal in the Adaohai Mine, Daqingshan Coalfield, Inner Mongolia, China: Modes of occurrence and origin of diaspore, gorceixite, and ammonian illite. Int. J. Coal Geol. 2012, 94, 250-270. [CrossRef]

36. Dai, S.; Ren, D.; Tang, Y.; Shao, L.; Li, S. Distribution, isotopic variation and origin of sulfur in coals in the Wuda coalfield, Inner Mongolia, China. Int. J. Coal Geol. 2002, 51, 237-250. [CrossRef]

37. Dai, S.; Ren, D.; Chou, C.L.; Finkelman, R.B.; Seredin, V.V.; Zhou, Y. Geochemistry of trace elements in Chinese coals: A review of abundances, genetic types, impacts on human health, and industrial utilization. Int. J. Coal Geol. 2012, 94, 3-21. [CrossRef]

38. Bai, J.; Li, W.; Bai, Z. Effects of mineral matter and coal blending on gasification. Energy Fuels 2011, 25, 1127-1131. [CrossRef]

39. Dai, S.; Wang, P.; Ward, C.R.; Tang, Y.; Song, X.; Jiang, J.; Hower, J.C.; Li, T.; Seredin, V.V.; Wagner, N.J. Elemental and mineralogical anomalies in the coal-hosted Ge ore deposit of Lincang, Yunnan, southwestern China: Key role of $\mathrm{N}_{2}-\mathrm{CO}_{2}$-mixed hydrothermal solutions. Int. J. Coal Geol. 2015, 152, 19-46. [CrossRef]

40. Li, F.; Huang, J.; Fang, Y.; Wang, Y. Formation mechanism of slag during fluid-bed gasification of lignite. Energy Fuels 2011, 25, 273-280. [CrossRef]

41. Liu, S.; Ma, W.; Zhang, Y.; Zhang, Y.; Qi, K. Sequential Transformation Behavior of Iron-Bearing Minerals during Underground Coal Gasification. Minerals 2018, 8, 90.

42. Ma, Z.; Bai, J.; Li, W.; Bai, Z.; Kong, L. Mineral transformation in char and its effect on coal char gasification reactivity at high temperatures, part 1: Mineral transformation in char. Energy Fuels 2013, 27, 4545-4554. [CrossRef]

43. Ward, C.R. Analysis and significance of mineral matter in coal seams. Int. J. Coal Geol. 2002, 50, 135-168. [CrossRef]

44. Wang, H.; Qiu, P.; Wu, S.; Zhu, Y.; Li, Y.; Zhao, G. Melting behavior of typical ash particles in reducing atmosphere. Energy Fuels 2012, 26, 3527-3541. [CrossRef]

45. Liu, S.; Qi, C.; Jiang, Z.; Zhang, Y.; Niu, M.; Li, Y.; Dai, S.; Finkelman, R.B. Mineralogy and geochemistry of ash and slag from coal gasification in China: A review. Int. Geol. Rev. 2018, 60, 717-735. [CrossRef] 
46. Dai, S.; Guo, W.; Nechaev, V.P.; French, D.; Ward, C.R.; Spiro, B.F.; Finkelman, R.B. Modes of occurrence and origin of mineral matter in the Palaeogene coal (No. 19-2) from the Hunchun Coalfield, Jilin Province, China. Int. J. Coal Geol. 2018, 189, 94-110. [CrossRef]

47. Ward, C.R. Analysis, origin and significance of mineral matter in coal: An updated review. Int. J. Coal Geol. 2016, 165, 1-27. [CrossRef]

48. Bhargava, S.K.; Garg, A.; Subasinghe, N.D. In situ high-temperature phase transformation studies on pyrite. Fuel 2009, 88, 988-993. [CrossRef]

49. Dai, S.; Zhao, L.; Hower, J.C.; Johnston, M.N.; Song, W.; Wang, P.; Zhang, S. Petrology, mineralogy, and chemistry of size-fractioned fly ash from the Jungar power plant, Inner Mongolia, China, with emphasis on the distribution of rare earth elements. Energy Fuels 2014, 28, 1502-1514. [CrossRef]

50. Mootabadi, H.; Salamatinia, B.; Bhatia, S.; Abdullah, A.Z. Ultrasonic-assisted biodiesel production process from palm oil using alkaline earth metal oxides as the heterogeneous catalysts. Fuel 2010, 89, 1818-1825. [CrossRef]

(C) 2019 by the authors. Licensee MDPI, Basel, Switzerland. This article is an open access article distributed under the terms and conditions of the Creative Commons Attribution (CC BY) license (http://creativecommons.org/licenses/by/4.0/). 